\title{
Kinematics, deformation partitioning and late Variscan magmatism in the Agly massif, Eastern Pyrenees, France
}

\author{
Jonas Vanardois ${ }^{1, *, a}$, Pierre Trap ${ }^{1}$, Philippe Goncalves ${ }^{1}$, Didier Marquer ${ }^{1}$, Josselin Gremmel ${ }^{1}$, \\ Guillaume Siron $^{2}$ and Thierry Baudin ${ }^{3}$ \\ ${ }^{1}$ UMR 6249 Chrono-environnement, Université de Bourgogne-Franche-Comté, 25030Besançon, France \\ 2 WiscSIMS Laboratory, University of Wisconsin-Madison, Madison, Wisconsin 53706, USA \\ ${ }^{3}$ BRGM-French Geological Survey, 3 Avenue Claude Guillemin, 45100 Orléans, France
}

Received: 20 August 2019 / Accepted: 14 April 2020

\begin{abstract}
In order to constrain the finite deformation pattern of the Variscan basement of the Agly massif, a detailed structural analysis over the whole Agly massif was performed. Our investigation combined geological mapping, reappraisal of published and unpublished data completed with our own structural work. Results are provided in the form of new tectonic maps and series of regional cross-sections through the Agly massif. At variance from previous studies, we identified three deformation fabrics named D1, D2 and D3. The D1 deformation is only relictual and characterized by a broadly northwest-southeast striking and eastward dipping foliation without any clear mineral and stretching lineation direction. D1 might be attributed to thickening of the Variscan crust in a possible orogenic plateau edge position. The D2 deformation is a heterogeneous non-coaxial deformation, affecting the whole massif, that produced a shallowly dipping S2 foliation, and an anastomosed network of C2 shear zones that accommodated vertical thinning and N20 directed extension. D2 is coeval with LP-HT metamorphism and plutonism at ca. 315$295 \mathrm{Ma}$. D2 corresponds to the extensional collapse of the partially molten orogenic crust in a global dextral strike-slip at the scale of the whole Variscan belt. The D2 fabrics are folded and steepened along a D3 eastwest trending corridor, called Tournefort Deformation Zone (TDZ), where the Saint-Arnac and Tournefort intrusives and surrounding rocks share the same NE-SW to E-W subvertical S3 foliation. Along the D3 corridor, the asymmetrical schistosity pattern and kinematic criteria suggest a D3 dextral kinematics. The D3 deformation is a record of E-W striking dextral shearing that facilitated and localized the ascent and emplacement of the diorite and granitic sheet-shaped plutons. D3 outlasted D2 and turned compressionaldominated in response to the closure of the Ibero-Armorican arc in a transpressional regime. The progressive switch from D2 thinning to D3 transpression is attributed to the lessening of gravitational forces at an advanced stage of extensional collapse that became overcome by ongoing compressional tectonic forces at the southern edge of the Variscan orogenic plateau.
\end{abstract}

Keywords: Crustal thinning / Variscan orogen / Gneiss dome / Agly Massif / Eastern Pyrenees

Résumé - Cinématiques, partitionnement de la déformation et magmatisme tardi-Varisque dans le massif de l'Agly, Pyrénées Orientales, France. Afin d'améliorer la compréhension du partitionnement de la déformation tardi-varisque dans le socle du massif de l'Agly, une nouvelle étude structurale a été menée. Elle a combiné un travail cartographique détaillé, la synthèse et l'harmonisation des données de la littérature complétées par notre propre analyse. Les résultats sont retransmis sous la forme de nouvelles cartes structurales et coupes géologiques à travers tout le massif. À la différence des études précédentes, nous avons clairement identifié trois fabriques de déformation nommées D1, D2 et D3. La déformation D1 est à l'état de relique et est caractérisée par une foliation S1 de direction générale NE-SW avec un pendage important vers l'Est, sans linéation minérale ou d'étirement clairement identifiable. D1 est interprétée comme témoignant de l'épaississement de la croûte Varisque au front d'un plateau orogénique. La

\footnotetext{
*Corresponding author: jonas.vanardois@univ-fcomte.fr

${ }^{a}$ Present address: 16 route de Gray, 25030 Besançon, France.
} 
déformation $\mathrm{D} 2$ est une déformation hétérogène et non coaxiale, affectant le massif entier, qui engendre une foliation S2 faiblement pentée et un réseau anastomosé de shear zones $\mathrm{C} 2$ accommodant un amincissement crustal et une extension vers le N20. D2 est contemporaine d'un métamorphisme de HT-BP et un épisode magmatique entre ca. 315 et $295 \mathrm{Ma}$. D2 correspond à une extension liée à l'effondrement gravitaire de la croûte orogénique partiellement fondue dans un contexte global décrochant dextre à l'échelle de la chaîne Varisque. La foliation S2 est plissée et verticalisée le long d'un couloir E-W D3, appelé Zone de Déformation de Tournefort (TDZ), où les intrusions de Saint-Arnac et de Tournefort et leurs encaissants partagent la même foliation S3 sub-verticale de direction NE-SW à E-W. Dans la TDZ, l'agencement asymétrique des schistosités et les critères cinématiques indiquent une cinématique D3 dextre. La déformation D3 correspond à un cisaillement transcurent $\mathrm{E}-\mathrm{W}$ dextre qui localise l'ascension et l'emplacement des plutons dioritiques et granitiques. La D3 s'initie dans l'infrastructure au cours de l'amincissement D2, elle perdure et reprend les fabriques D2 dans un régime transpressif dextre dominant en réponse probable à la fermeture de l'Arc Ibéro-Armoricain. Le passage progressif de l'amincissement D2 à la transpression D3 est attribué à la diminution des forces gravitaires à un stade avancé de l'effondrement gravitaire suivi par la reprise les forces tectoniques compressives en bordure de plateau orogénique. Nos résultats confirment aussi que le rifting Crétacé ne provoque pas de déformation ductile mylonitique dans les roches métamorphiques du massif de l'Agly.

Mots clés : amincissement crustal / orogénèse Varisque / dôme gneissique / massif de 1'Agly / Pyrénées Orientales

\section{Introduction}

In hot and mature orogens, the dynamic nature of lateorogenic evolution results in the preservation of a complex set of spatially and temporally partitioned deformational, metamorphic and magmatic events. Feedback relationships in time and space between those events control the balance of gravitational $v s$. boundary forces that drive the crustal flow, especially within orogenic plateaus featuring a large, hot and weak crust.

Mechanical re-equilibration of the orogenic plateau lead to crustal thinning in its inner part and lower crustal flow toward the foreland where compression and thickening occur (e.g. Dewey, 1988; Rey et al., 2010). With ongoing orogenic collapse, further extension and thinning move toward the plateau edges and interact with the deep crust that is continuously subjected to compression, lateral flow and exhumation. On these particular external domains, late orogenic gravitational collapse is responsible for superimposition, in time and space, of contractional and extensional structures the depiction of which is not straightforward but essential to unraveled in order to fully understand lateral and horizontal crustal flow and exhumation of deep crust.

The aforementioned tectonic evolution is well exemplified in the European Variscides where a Tibetan-style orogenic plateau is proposed to have collapsed during the middle Carboniferous-early Permian period (e.g. Dörr and Zulauf, 2010; Whitney et al., 2015; Maierová et al., 2016). In France, the French Massif Central (FMC) has been proposed as an example of plateau internal zone, and the Variscan Pyrenees as the plateau edge or foreland with, in between, the Montagne Noire massif (MN) located at the plateau-foreland transition (Whitney et al., 2015). The eastern FMC recorded regional scale extensional collapse and exhumation of the deep partially molten crust (e.g. Malavieille et al., 1990; Burg et al., 1994; Vanderhaeghe et al., 1999; Ledru et al., 2001). The MN gneiss dome is considered to have formed at the edge of the collapsing Variscan orogen during Late Carboniferous time (Franke et al., 2011; Whitney et al., 2015). More to the south, the Variscan Pyrenean belt would represent the outer border of the orogenic plateau that share similar structural, metamorphic and magmatic features with the Montagne Noire gneiss dome located at the plateau-foreland transition (Whitney et al., 2015). However, uncertainties still exist about the relative position of Variscan Pyrenean massifs located south of the North Pyrenean Fault, i.e. in the Pyrenean Axial Zones, with respect to the FMC and MN. Conversely, the eastern North Pyrenean Massif and in particular the Agly massif may represent a direct southward prolongation of the southern FMC massifs. Unfortunately, this external domain still lacks detailed structural constrains on late-Variscan history in order to understand the complex three-dimensional internal deformations in the Variscan orogen edge that interlinked gravitydriven extensional collapse, voluminous partial melting, magma emplacements, thermal softening and plate-boundary forces under wrench tectonic.

The present study investigates the three-dimensional deformation of the Agly massif as an example of the orogenic plateau foreland during late-Carboniferous-early Permian time. We have identified a detail geometry of the structures with a polyphased deformation history. The structural analysis of macro and microstructures has been linked to metamorphic and magmatic events for which accurate $\mathrm{P}-\mathrm{T}$ and geochronological constraints are available from the literature. The finite strain pattern of the Agly massif is discussed and replaced in the tectonic framework of the Variscan orogeny considering a progressive switch from gravitational collapse to dextral transpression in a syn-plate convergence context.

As part of the Pyrenean mountain range, the Agly massif recorded both the Variscan and Alpine orogenic cycles. The complex polyphased nature of the Pyrenees is exposed in the North Pyrenean Zone (NPZ, Figs. 1 and 2A), where Paleozoic high-grade metamorphic massifs of Variscan basement, the North Pyrenean massifs (NPMs), are tectonically juxtaposed with fragments of subcontinental mantle and metamorphic Mesozoic sediments in response to Cretaceous extension (e.g. Clerc et al., 2015, 2016; Clerc and Lagabrielle, 2014; Lagabrielle et al., 2016; Ducoux, 2017). Most of the NPMs are characterized by numerous shallowly dipping extensional ductile shear zones and an anomalous HT-LP metamorphic gradient (e.g. Thiébaut, 1964; Roux, 1977; de Saint Blanquat, 1989, 1993; de Saint Blanquat et al., 1990; Paquet and Mansy, 1991; Guitard et al., 1996). Although these structures and 


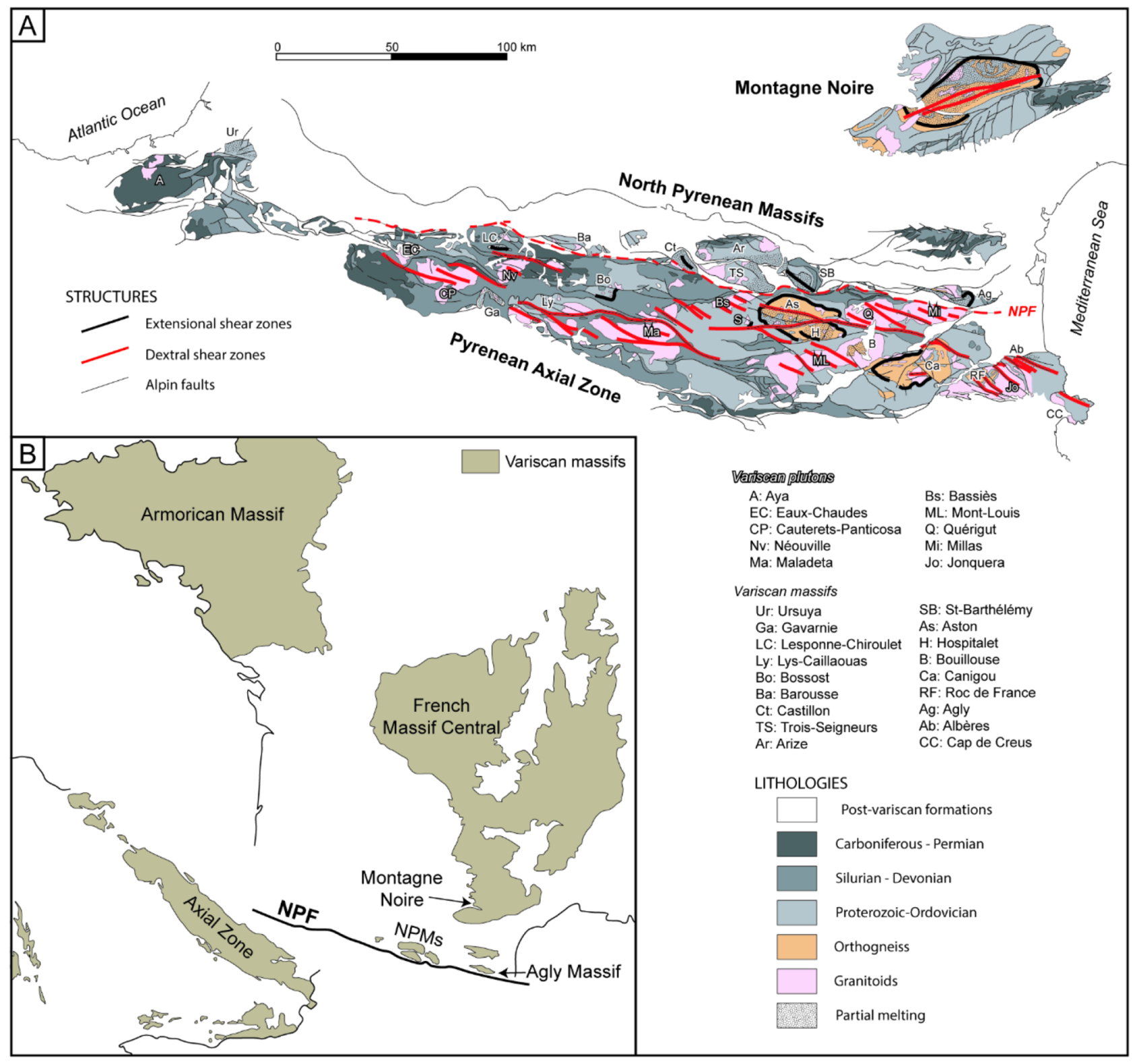

Fig. 1. (A) Map of the Variscan Pyrenees and of the Montagne Noire massif with main Variscan shear zones. (B) Probable position of the Variscan massif at the end of the Variscan orogeny, modified from Carreras and Druguet (2014).

metamorphism have been related to the Paleozoic Variscan orogeny (e.g. de Saint Blanquat, 1989, 1993; de Saint Blanquat et al., 1990), some studies highlight the possible impact of Cretaceous extension on the structuration on the Variscan Agly massif basement (Delay, 1989; Vauchez et al., 2013; Odlum and Stockli, 2019). We further discuss this secondary point in the light of our new structural data.

\section{Geological Setting}

\subsection{The Variscan Pyrenees in the Western European Variscan Belt}

Within the Western European Variscan Belt, the Variscan Pyrenees, i.e., the Pyrenean Axial Zone (AZ) and the North Pyrenean Zone (NPZ), belong to the external domain corresponding to the southern orogenic foreland (e.g. Burg et al., 1994; Edel et al., 2018). The Variscan Pyrenees are composed of Proterozoic to Paleozoic sediments that were metamorphosed and deformed from middle Carboniferous to early Permian time (e.g. Aguilar et al., 2013; Denèle et al., 2014; Mezger and Gerdes, 2016). The Variscan metamorphism is characterized by a high temperature and low pressure HT/LP gradient conducing to intense partial melting of the lower and middle crust. It is attributed to a high mantle flux and to emplacements of numerous basic and acid plutons (Guitard et al., 1996 and references therein; Lemirre, 2016). Two main deformation events are described in the Pyrenean Axial Zone: (i) a nappe stacking toward the south D1 responsible for moderate crustal thickening (e.g. Carreras and Capella, 1994; Matte, 2002; Vilà et al., 2007; Denèle et al., 2009, 2014; Laumonier et al., 2010; Aguilar et al., 2015), followed by (ii) a 


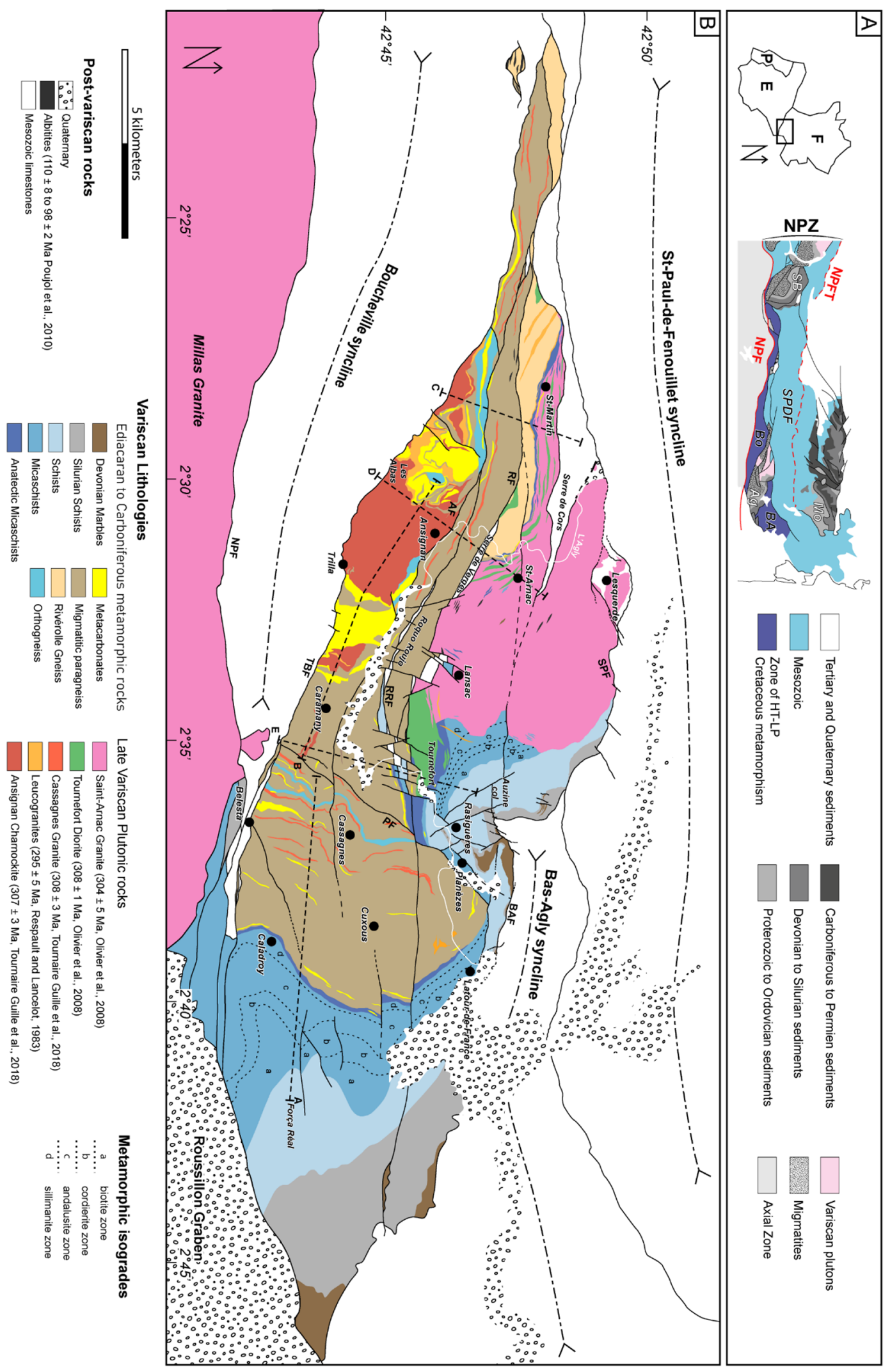

Fig. 2. (A) Location of the North Pyrenean Zone and map of the principal geological formations of the area. (B) Geological map of the Agly Massif modified from Fonteilles et al. (1993) and Delay (1989). The location of cross-sections of Figures 4 and 10 is indicated. NPF: North Pyrenean Zone; TBF: Trilla-Bélesta Fault; AF: Ansignan Fault; RF: Rentadou Fault; RRF: Roquo Roujo Fault; PF: Planèzes Fault; BAF: BasAgly Fault; SPF: Saint-Paul Fault. 
dextral transpressive regime D2 forming several gneiss-domes and dextral reverse shear zones allowing emplacement of large plutons (Fig. 1; Gleizes et al., 1997, 1998a, 2001; Denèle et al., 2009, 2014; Laumonier et al., 2010; Cochelin et al., 2017). Several flat extensional shear zones are also described (Fig. 1; Gibson, 1991; Vissers, 1992; Mezger and Passchier, 2003) that are interpreted as evidence for transtensional exhumation of migmatitic dome in a global transpressional regime (Cochelin et al., 2017). North of the North Pyrenean Fault (NPF), the North Pyrenean Zone mainly also recorded the same HT/LP metamorphism. Conversely to the $\mathrm{AZ}$, the main fabric is defined by a penetrative flat-lying foliation that developed during retrogressive metamorphism during a continous extensional event (de Saint Blanquat et al., 1990; Bouhallier et al., 1991). A full and detail review of the geodynamic evolution of the Western European Variscan belt during Late Palaeozoic times can be found in recent contributions (Cochelin et al., 2017; Ballèvre et al., 2018; Edel et al., 2018).

\subsection{Geological outline of the Agly Massif (AM)}

The Agly massif is the easternmost NPMs (Fig. 1). It is a $30 \mathrm{~km}$-long and $10 \mathrm{~km}$-wide Variscan massif bounded by three Mesozoic basins: the Boucheville syncline to the south, the Bas-Agly syncline to the Northeast, and the St-Paul-deFenouillet to the North (Fig. 2). The Cenozoic (Pliocene) Roussillon Graben sedimentary infilling delimits the southeastern border of the massif. The Paleozoic and Mesozoic structural domains are separated by E-W trending vertical Alpine faults (Fig. 2B).

The Variscan basement consists of a $6 \mathrm{~km}$-thick metamorphosed Ediacarian to Devonian sedimentary sequence (Fonteilles, 1970; Berger et al., 1993; Casas and Palacios, 2012). The deepest part of the sequence also contains abundant meter to decameter-thick sheets of orthogneisses that correspond to former granitic sills emplaced at ca. $540 \mathrm{Ma}$ (Tournaire Guille et al., 2018). The para- and ortho-derived sequence has been metamorphosed and deformed during the late Variscan orogeny between ca. 305 and 295 Ma (Siron et al., 2012, 2020). Considering structural depths and metamorphic grade, Delay (1989) made a two-fold subdivision of the AM basement into an infrastructure and a suprastructure, separated by the anatectic front. The infrastructure consists of partially molten orthogneisses and paragneisses hosting layers of marbles and calc-silicates. The suprastructure consists of the upper part of the metasedimentary series with Cambrian to early Ordovician micaschists and schists (the so-called Jujols group, Laumonier, 1998), thin and discontinuous late Ordovician volcano-clastic rocks, Silurian black-schists and Devonian marbles (Fig. 2B).

Both the supra- and infrastructure are intruded by late Variscan (308-304 Ma) magmatic bodies. The Ansignan charnockite is a 600 meter-thick laccolith that has intruded the deepest part of the infrastructure, in the southwestern part of the massif, at $307 \pm 3 \mathrm{Ma}$ (Tournaire Guille et al., 2018). This magmatic complex is made of two main magmatic rocks (1) a porphyric K-feldspar, garnet and orthopyroxene-bearing granodiorite and (2) a garnet-bearing leucogranite best observed in the intrusion roof (e.g. Albas locality). Norite and diorite bodies are also reported within the charnockite (Delay, 1989; Berger et al., 1993; Althoff et al., 1994, Olivier et al., 2008). The Cassagnes granite occurs as several metric to decametric sills in the upper part of the infrastructure (Fig. 2B). It is very similar in composition to the charnockite, except that orthopyroxene is very rarely observed, but was emplaced at the same time at $308 \pm 3 \mathrm{Ma}$ (Tournaire Guille et al., 2018). Older ages have been proposed for the emplacements of the Ansignan and Cassagnes sills at ca. $315 \mathrm{Ma}$ (Postaire, 1982; Respaut and Lancelot, 1983; Olivier et al., 2004), The Tournefort diorite and the Saint-Arnac granite intruded the schists and micaschists of the suprastructure (Fig. 2B). Olivier et al. (2008) proposed that these two plutons were cogenetic and that they emplaced between $308 \pm 1$ and $304 \pm 5 \mathrm{Ma}$ respectively. The Saint-Arnac pluton is also composed of several acid intrusions (Fonteilles et al., 1993; Olivier et al., 2008). The diorite induced local contact metamorphism responsible for limited partial melting of the surrounding micaschists (Delay, 1989; Fig. 2).

Heat advection associated with the upward transfer of the large volume of magmatic bodies may have contributed to the regional HT/LP metamorphism during the late-Variscan orogeny (Vielzeuf, 1984; Delay, 1989; Guitard et al., 1996; Olivier et al., 2004; Siron et al., 2012, 2020). This is consistent with the recent temporal constraints of the HT-LP peak temperature dated at ca. $305 \mathrm{Ma}$ with in situ LA-ICP-MS on monazite and zircon (Siron et al., 2012, 2020; Tournaire Guille et al., 2018). The suprastructure is characterized by a HT-LP metamorphism recorded with the successive apparition of biotite, cordierite, andalusite and sillimanite as index minerals (Fonteilles et al., 1993). Here, the geothermal gradient in the suprastructure has been recently reconstructed at $55^{\circ} \mathrm{C} / \mathrm{km}$ (Siron et al., 2012). Temperature reached up to $680^{\circ} \mathrm{C}$ at the base of the suprastructure (Delay, 1989; Bouhallier et al., 1991; Siron et al., 2012, 2020), triggering the onset of partial melting outside the stability field of muscovite. Below the anatectic front, the infrastructure is characterized by a nearly isothermal geothermal gradient $\left(\sim 8^{\circ} \mathrm{C} / \mathrm{km}\right)$ during late Variscan event, with temperatures comprised between $730-800^{\circ} \mathrm{C}$ (Andrieux, 1982a, b; Vielzeuf, 1984; Delay, 1989; Bouhallier et al., 1991). This has been interpreted as the consequence of thermal buffering due to the highly endothermic behavior of the biotite dehydration-melting reaction (Delay, 1989; Siron et al., 2012, 2020).

Comparison between thermobarometric estimations and present-day thickness suggests that between 3 and $5 \mathrm{~km}$ of the crust were subtracted during thinning (Andrieux, 1982a, b; Vielzeuf, 1984; Delay, 1989; Bouhallier et al., 1991; Paquet and Mansy, 1991; Siron et al., 2012, 2020) responsible for tightening of metamorphic isograds closer and the apparent strong metamorphic gradient between $80^{\circ} \mathrm{C}$ and $125^{\circ} \mathrm{C} / \mathrm{km}$ (Guitard et al., 1996 and references therein; Siron et al., 2012, 2020).

The HT/LP metamorphism is related to main strain pattern observed over the AM that corresponds to a pervasive flatlying foliation and localized mylonites holding an NNE-SSW trending stretching lineation. The foliation is flat-lying in the southern part of the massif, and is very steep and E-W striking in the northwestern part of the massif (Figs. 2 and 3; Berger et al., 1993; Fonteilles et al., 1993). It is synchronous with high-grade metamorphism, partial melting and sheet-shaped granitoid intrusions, the latter showing a magmatic foliation concordant with the gneissic surrounding main foliation 
(Delay, 1989; Bouhallier et al., 1991; Paquet and Mansy, 1991; Althoff et al., 1994).

Mylontic to ultramylonitic ductile shear zones are distributed over the whole structural pile. Delay (1989) and Paquet and Mansy (1991) have identified about ten gently dipping mylonitic shear zones of various thicknesses (meter to decameter) that are parallel to the main foliation with a very conspicuous N20 stretching direction. Based on the kinematics of these shear zones (top-to-the-north in the northern part and top-to-the-south in the southern part), Olivier et al. (2004, 2008) suggested that these shear zones were localized at the top of the dome roof at ca. $300 \mathrm{Ma}$ as the final stage of a doming under transpressional evolution. In contrast, Bouhallier et al. (1991) proposed that top-the-north shear zones are linked to an extensional detachment at the boundary between anatectic micaschists and gneisses, likely responsible for the juxtaposition of the infrastructure and suprastructure during a lateVariscan extension. Based on in situ LA-ICP-MS on monazite of mylonitic gneisses, Siron et al. $(2012,2020)$ proposed that this thinning occurred at ca. 300-296 Ma. Olivier et al. (2004) have suggested instead that the subtraction and thinning did not occur via a single shear zone and proposed that the material was subtracted by many small shear zones at the top of a late Variscan diapiric dome in both the infrastructure and suprastructure.

An earlier tectonic phase is attributed to crustal thickening with relics of kyanite (Fonteilles, 1970; Fonteilles and Guitard, 1971) and moderately dipping relictual foliation with south verging sheath folds interpreted as top-to-the-south shearing and nappe stacking (Bouhallier et al., 1991; Olivier et al., 2004).

In the Mesozoic sediments of the Bas-Agly and Boucheville synclines, the impact of Cretacous extension is supported by HT-LP metamorphism in (Golberg and Leyreloup, 1990) and highlighted by Raman Spectrometry on Carbonaceous Matter (RSCM) studies that reported temperatures up to $550{ }^{\circ} \mathrm{C}$ (Clerc, 2012; Chelalou, 2015; Chelalou et al., 2016; Ducoux, 2017) as a result of the Cretaceous crustal thinning and mantle uplift (Clerc and Lagabrielle, 2014; Clerc et al., 2015, 2016; Chelalou et al., 2016; Lagabrielle et al., 2016; Ducoux, 2017). In that context, the late Variscan age of the ultramylonitic shear zones has been questioned since the 1990's (Delay, 1989; Paquet and Mansy, 1991; Vauchez et al., 2013; Odlum and Stockli, 2019). Mylonitic deformation of Mesozoic limestone at the base of the Bas-Agly syncline, with a N20 stretching direction similar to that affecting the metamorphic basement led Delay (1989) and Vauchez et al. (2013) to suggest that part of the ductile shear in the Agly basement may be attributed to Cretaceous extension. More recently, Odlum and Stockli (2019) have shown that U-Pb apatite ages from the southern side and deepest part of the Agly massif were reset between 113 and $123 \mathrm{Ma}$ while those located to the north still preserved late Variscan ages. This difference in thermal history led them to suggest that the high-grade gneisses of the southern part of the massif are part of the lower crust and were exhumed and juxtaposed to the micaschists of the northern part of the massif, interpreted as the upper crust, during early Cretaceous extension.

The Paleozoic basement is cut by steeply dipping E-W to NW-SE trending faults interpreted as ancient sinistral faults formed during the opening of pull-apart basins infilled with
Mesozoic carbonates (e.g. the Serre de Verges, Roquo Roujo, the Serre de Cors; Fig. 2B; Fonteilles, 1970, 1976). These major faults drain hydrothermal fluids with temperatures between 300 and $550{ }^{\circ} \mathrm{C}$ (Fallourd et al., 2014; Boulvais, 2016). Hydrothermalism locally resulted in an almost complete albitization of the Paleozoic rocks, like de Saint Arnac granite and surrounding gneisses between 110 and $95 \mathrm{Ma}$ (Poujol et al., 2010). Recently, using (U-Th)/He method on apatite and zircon in the Agly Massif's Paleozoic rocks, Ternois et al. (2019) estimated the temperature of the Cretaceous thermal event related to fluid circulation along the E-W brittle structures at a maximum of $300^{\circ} \mathrm{C}$. Using RSCM, Ducoux (2017) reported a temperature of $420^{\circ} \mathrm{C}$ in the Serre de Verges Mesozoic limestones.

The Mesozoic basins fringing the Agly Massif together with the small pull-apart basins were inverted during Tertiary collision, and pinched between steep reverse faults and overthrusted towards the North. The main reverse faults cutting the Paleozoic basement are from north to south, the Serre de Cors, the Rentadou and the Roquo Roujo (Fig. 2B) delimiting ribbons of NPMs. The faults show top-to-the-north kinematics and exhumed the southern blocks (Delay, 1989). The last stage of the brittle deformation is manifested by N20 and N150 striking conjugate strike-slip faults that accommodated the N$\mathrm{S}$ directed Pyrenean shortening. Among these strike-slip faults, the sinistral NE-SW trending Planèzes Fault (Fig. 2B) may have accommodate a large displacement already during late Variscan and may have been reactivated during Pyrenean Tertiary Tectonics.

In the following, we present the results of a detailed structural analysis focused on Variscan deformation, and performed over the whole Agly massif, with a reappraisal geological mapping, new tectonic maps and series of detailed cross-sections. At variance from previous studies, we clearly identified three Variscan deformation fabrics named D1, D2 and D3 deformations responsible for the present finite strain pattern of the AM. The deformation history in order to correlate new and existing structural, metamorphic, magmatic and geochronological datasets.

\section{Overall geometry and deformation partitioning in the Agly massif}

The structural maps on Figure 3 present the dataset of more than 3000 foliation and lineation measurements from our own field surveys and from published mapping of Delay (1989). Two main areas are defined: (i) a southern domain, that extends south of a line going from Ansignan to Latour-de-France villages, where the foliation is moderately to gently dipping and the stretching and mineral stretching lineation trends consistently N20; (ii) a northern domain where the foliations are steeply dipping to vertical and generally E-W directed (Figs. 3A-3C). However, microstructural observations and the structural data suggest that the overall finite strain pattern of the Agly massif resulted from the superposition of three major ductile deformations, named D1, D2 and D3, and a local D4 deformation that is only present in the vicinity of the Eastern margin of the Saint-Arnac granite (cf. section 4.2). In this scheme, the southern and northern domains are mostly dominated by the S2 foliation and the steeply dipping S3 

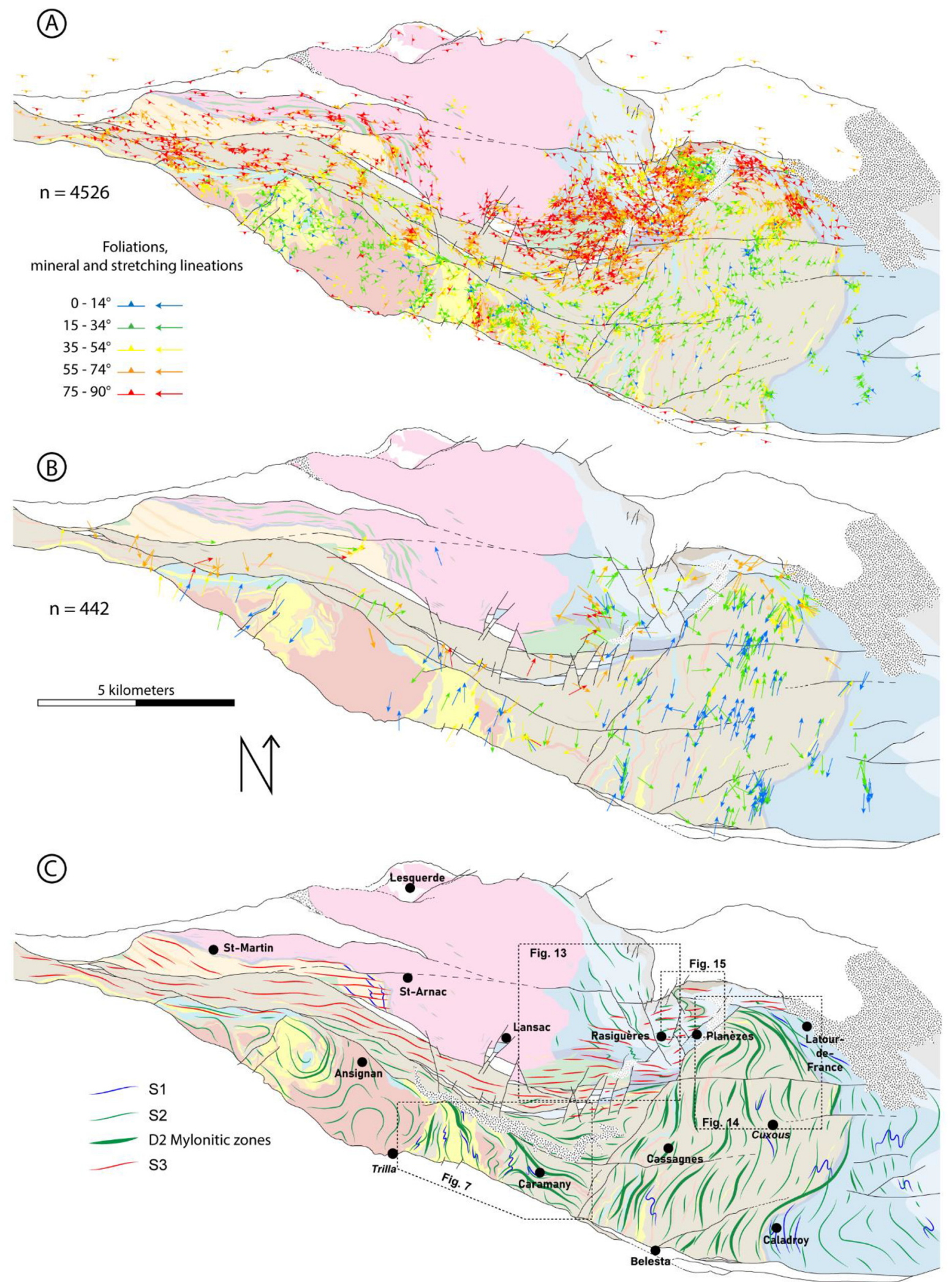

Fig. 3. Maps of the Agly massif showing (A) foliations and (B) lineations measurements from this study and Delay (1989). (C) Synthetic map showing the foliation simplified trajectories of D1, D2 and D3 deformation. Zoom areas of Figures 6, 12, 13 and 14 are indicated. 
foliation, respectively (Fig. 3). We further document the geometrical relationships between D1, D2, D3 and D4 and their kinematics in key areas with detailed structural mapping and deformation analyses, focusing on the relationships between deformation, metamorphism, partial melting and magma emplacement.

\subsection{D1 deformation}

The D1 fabrics are observed in the whole massif as a relictual deformation preserved from D2 or D3 reworking. In the eastern part of the southern domain, where low-grade schists are exposed east of Caladroy and Latour de France, the D1 planar fabrics correspond to a S1, mainly parallel to the sedimentary bedding, that is mostly concordant to the flat lying $\mathrm{S} 2$ (Fig. 4 stereograms 1 and 2). The S0-1/S2 relationship is best observed on centimeter- to meter-scale F2 fold hinges in the low grade schist (Figs. 6A-6C) and the Devonian marbles (Fig. 6D). In the gneissic and migmatitic part of the massif, S1 is preserved in ten to hundred meter scale lense-shaped low-D2 strain domains as a moderately to steeply dipping and NE-SW to NW-SE-trending relict S1 foliation (Figs. 5 and 7). In these lenticular domains, the flat lying S2 foliation is pervasive but remains weak.

The S1 enveloping surface is NW-SE (mostly N150E) trending and dips steeply to moderately toward the NE with a stretching and mineral lineation L1 gently plunging SE. S1 is commonly folded and transposed by S2 (Figs. 4, 6 and 7). In the low grade schist of the eastern part of the southern domain, both $\mathrm{S} 1$ and $\mathrm{S} 2$ are defined by preferential alignment of chlorite, white mica and biotite (Fig. 6B). In the infrastructure, $\mathrm{S} 1$ and S2 foliations are outlined by biotite and elongated quartzo-feldspathic aggregates or peritectic minerals like cordierite or garnet (Figs. 6F and 6G). The mineralogical assemblages that define the D1 planar and linear fabrics are similar to the D2 parageneses, preventing any D1/D2 distinction based on metamorphic characters.

The large-scale S1-S2 geometrical pattern is best observed along an E-W trending cross-section (Figs. 5 and 7B) making a foliation envelope that undulates with two predominant orientations. This pattern is well marked in the southern part of the massif where several authors mentioned or represented map-scale folds with N-S trending axis (Delay, 1989; Berger et al., 1993; Tournaire Guille et al., 2018). Delay (1989) proposed that these folds were formed by the emplacement of the Ansignan charnockite, at odds with the concordance between the magmatic foliation and the foliation of countryrock ( $c f$. section 4.1). In this area, the low-D2 strain lens are larger and more numerous (Fig. 7), forming alternations between steep S1 and nearly horizontal S2 (Figs. 5 and 7). Relicts of D1 preserved in the D3 domain are observed in the easternmost termination of the D3 deformation corridor and southwest of the Saint-Arnac pluton.

\subsection{D2 deformation}

Throughout the whole massif, D2 is defined by a pervasive flat lying S2 foliation that holds a N10-20 trending stretching and mineral lineation L2 (Figs. 4, 5 and 8). As originally described by Pascal et al. (1976), numerous F2 folds reworking S1 with an S2 axial plane as schistosity and fold axis that commonly parallel L2 are observed in the gneisses and micaschists. In the eastern part of the massif, S2 foliation is parallel to the metamorphic isograds that are characteristic of the HT-LP metamorphic gradients (biotitein, cordierite-in, andalusite-in, sillimanite-in, muscovite-out and melt-in isograds). The L2 is outlined by preferential alignment of biotite, pressure shadow around sulfides or elongated cordierite and andalusite porphyroblasts (Fig. 8). In the infrastructure, $\mathrm{S} 2$ is defined by a gneissic and migmatitic layering. Numerous granitic leucosomes are parallel to S2 or intrude along F2 fold axial plane, but without any internal plastic deformation, arguing for a syn-migmatitic D2 deformation. The migmatitic foliation holds a L2 lineation marked by preferential alignment of biotite $+/-$ sillimanite aggregates. These observations indicates that D2 were coeval with the HT-LP metamorphism (M2).

Shear criteria along L2 is consistent with a bulk top-to-thenorth shearing. Localized high-D2-strain zones (C2) are observed as centimeters to ten meters wide mylonitic to ultramylonitic shear zones in the whole structural pile. They lie parallel or slightly oblique to the main S2 foliation (Fig. 9). These C2 shear zones form an anastomosing network of that separates lense-shaped D2-moderate strain domains. In the infrastructure, we have observed major $\mathrm{C} 2$ shear zones that form high strain corridors of anastomosed 20-30 meter-thick mylonites called Cuxous, Caramany, western Ansignan and eastern Ansignan shear zones (Figs. 3 and 5). Another major shear zone (Caladroy shear zone, Bouhallier et al., 1991) is located at the interface between the infrastructure and the suprastructure. C2 shear zones bear a well-defined L2 mineral stretching lineation parallel to that of the lower-strain domains formed by elongate and recrystallized $\mathrm{Bt}+\mathrm{Qtz}+\mathrm{Kfs}$ aggregates, with a conspicuous N20 direction (Fig. 8). Kinematic indicators suggest a main top-to-the north shearing observed either in the infrastrusture or in the suprastructure (Fig. 9). C2 mylonitic shear zones are often internally affected by $C$ ' shear bands that show a similar top-to-the north sense of shear. Although top-to-the-north shearing is the most conspicuous kinematics, top-to-the-south shearing is also reported at different places in the massif and is interpreted as conjugate faults (e.g. Bouhallier et al., 1991; Olivier et al., 2004).

Within the deepest rocks of the infrastructure, strain gradients across $\mathrm{C} 2$ shear zones show that mylonitic texture developed progressively from the migmatitic foliation without significant changes in the metamorphic assemblages (Fig. 10). Dynamic recrystallization of migmatitic phases produced layers of very fine grained $\mathrm{Qtz}+\mathrm{Kfs}+\mathrm{Bt}+\mathrm{Grt} \pm \mathrm{Sil} \pm \mathrm{Crd} \pm$ Opx assemblage. Plastic flow is accompanied by brittle fracturing of large K-feldspars, garnets and orthopyroxenes (when present). Brittle fracturing and boudinage of the porphyroblasts developed in the presence of water and are responsible for local high-temperature retrogression with the crystallization of syn-kinematic $\mathrm{Bt}+\mathrm{Sil}+\mathrm{Qtz}$ assemblage. Although localized, the mylonitic deformation is homogeneously distributed over the entire gneissic and migmatitic domain.

Within higher structural levels of the infrastructure, along the Cassagnes, Cuxous and Caladroy high-strain zones, mylonitic fabrics are characterized by a fine grained matrix of plastically-deformed quartz aggregates that mantles 
cataclased feldspars (Fig. 10). Quartz deforms plastically whereas cataclasis of feldspar megacryst, imbrication and boudinage is common. Boudin necks show syn-kinematic growth of biotite. Within the ultramylonitic foliation, the quartz-feldspar grain-size is very low $(5-10 \mu \mathrm{m})$ and trails of fractured garnets show rare and weak retromorphosis with $\mathrm{Bt}+\mathrm{Chl}+\mathrm{Qtz}$ assemblage. In some samples, chlorite seems to be post-kinematic as related to late alteration of biotite.

\subsection{The D3 “Tournefort Deformation Zone” (TDZ)}

In the Northern part of the massif, the S2 foliation is affected by a D3 deformation localized along an E-W trending and $4 \mathrm{~km}$-wide strain zone, named the Tournefort Deformation Zone (TDZ). The TDZ crosscuts the whole massif from west to east (Figs. 3 and 11) forming subvertical D3 planar fabrics with strikes ranging from ENE-WSW to ESE-WNW (Fig. 4). The Tournefort dioritic intrusion is also affected by this D3 deformation. The TDZ is cut by the Late Variscan Planèzes fault system that induces a bulk sinistral offset of about $3 \mathrm{~km}$ in map view (Figs. 2B and 3).

A gradient of deformation can be observed from the margins to the core of the TDZ (Fig. 11). The D3 TDZ margins are characterized by a progressive folding of the initially shallowly and eastward dipping S2 foliation into a NE-SW direction with a steeper dip (Fig. 11). The margins of the D3 TDZ show F3 folds with a steep NE-SW striking axial surface and weakly plunging axes (Figs. 12A-12C and 13C). F3 axial planes can be associated with the development of a NE-SW subvertical S3 cleavage, like in the Devonian limestone (Fig. 12B).

With increasing D3 deformation towards the core of the TDZ, F3 folds become tighter leading to the intensification of S3 cleavage with an E-W strike. L3 mineral stretching lineations are very scarce and have variable plunge (Fig. 12D). In sections parallel to the stretching lineation (XZ deformation principal plane) where it is horizontal, D3 dextral kinematic criteria are recognized in the micaschists in the form of S-C fabrics and sigma feldspar-clasts in the gneisses (Fig. 12C).

Within the TDZ, two sets of centimeter to decametric subvertical dextral shear zones are observed with N120 and few N90 directions (Fig. 13C). The N120 shear zones are located mainly in the core of the TDZ. The inflexion of S2-S3/ C3 observed along these shear zones is consistent with apparent dextral shearing. East of Tournefort diorite and west to the Saint-Arnac granite, the E-W striking S3 is transposed into a NW-SE trend ( N120) shear zones and also emphasizes an apparent dextral shearing (Fig. 3). The NE-SW to NW-SE spread of poles of D3 planar fabrics (i.e. S2-S3/C3) on stereograms from (Figs. 4 and 13) is explained by the D3 gradient of deformation (Fig. 13C).

Between Planèze and Latour-de-France village, the gently eastward dipping S2 foliation progressively rotates at a kilometer scale towards an E-W and sub-vertical orientation and forms a kilometer F3 fold (Fig. 14). The S3 foliation is scarce and not pervasive in this area (not represented on the Fig. 14), whereas it is penetrative in the western part of the dome (Figs. 14C and 14D). It is worth noting that together with the D2 anastomosing network, the S2 and L2 mylonites and ultramylonites are also affected by the D3 folding (Fig. 14).
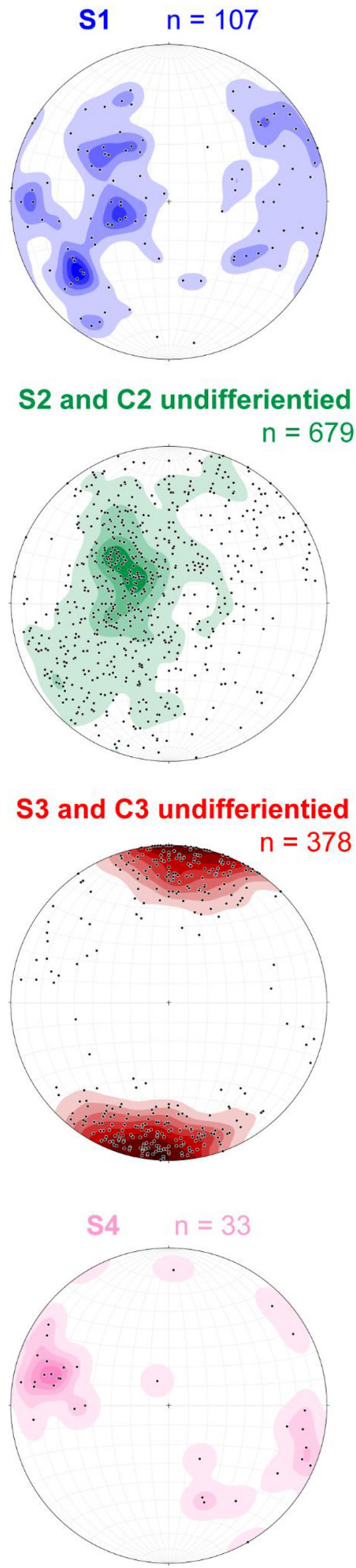

Fig. 4. Poles of planar fabrics of each deformation (D1, D2, D3 and D4) plotted in lower hemisphere Wulf stereograms. Only data with a clear affiliation to one of the four deformations are represented. 


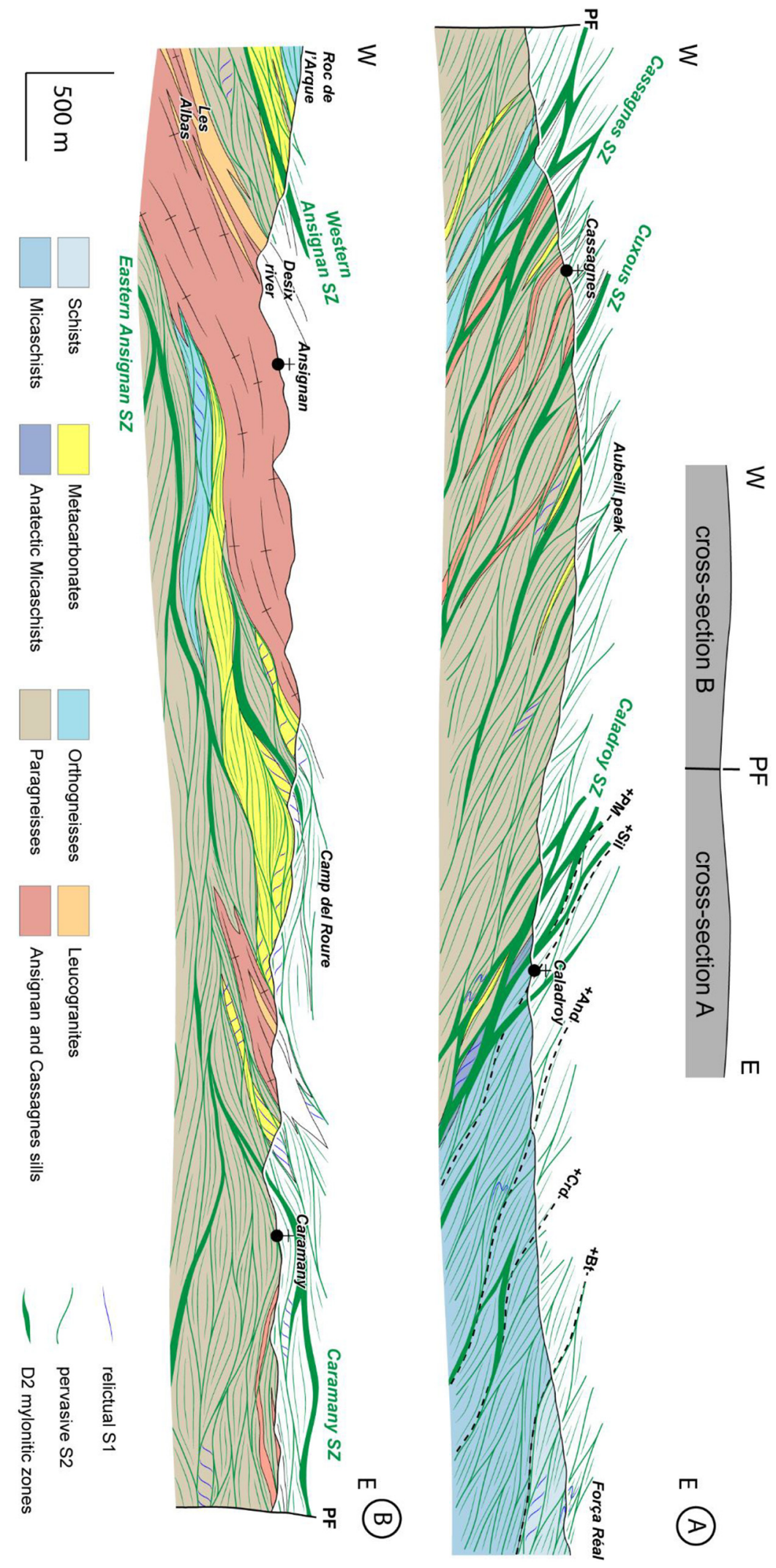

Fig. 5. E-W Cross-sections through the Agly massif. (A) eastern side of Planèzes fault. (B) Southern part of the Agly Massif, in the western side of Planèzes fault. (PM: partial melting). 

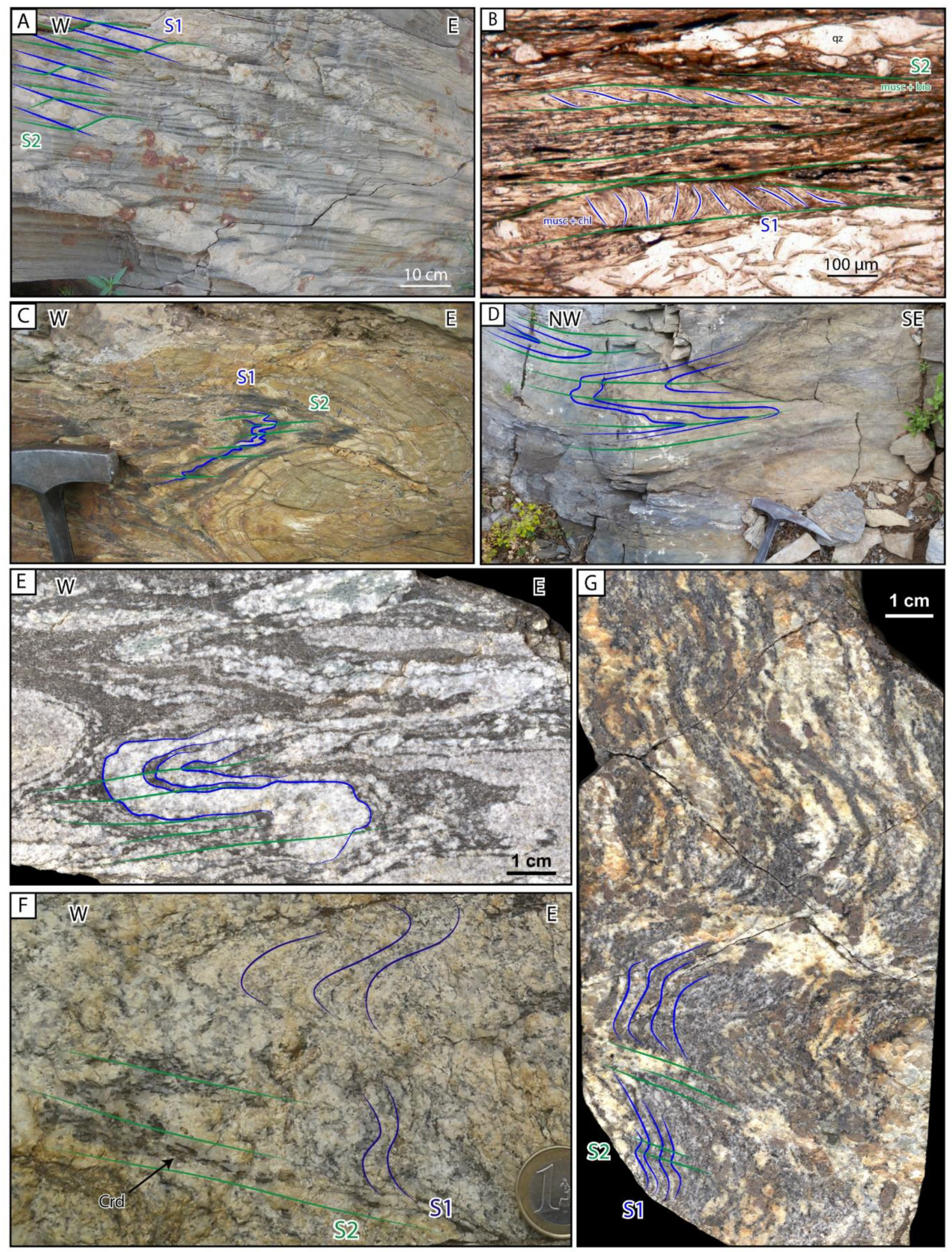

Fig. 6. Outcrop and microphotographs showing D1/D2 relationships. In Força Réal schists, (A) S2 in S0-1 quarzitic layers; (B) remnants of S1 in thin-section, S1 bears chlorites and muscovites, and S2 muscovites and biotites; F2 foldsin (C) Força Réal schists, (D) devonian marbles, (E) migmatitic paragneiss. (F) F2 folds in migmatitic paragneiss, cordierites are crystallized parallel to S2 inside leucosomes coeval with D2 deformation. $(\mathrm{G}) \mathrm{F} 2$ folds in migmatitic paragneiss with injections of melts parallel to $\mathrm{S} 2$. 


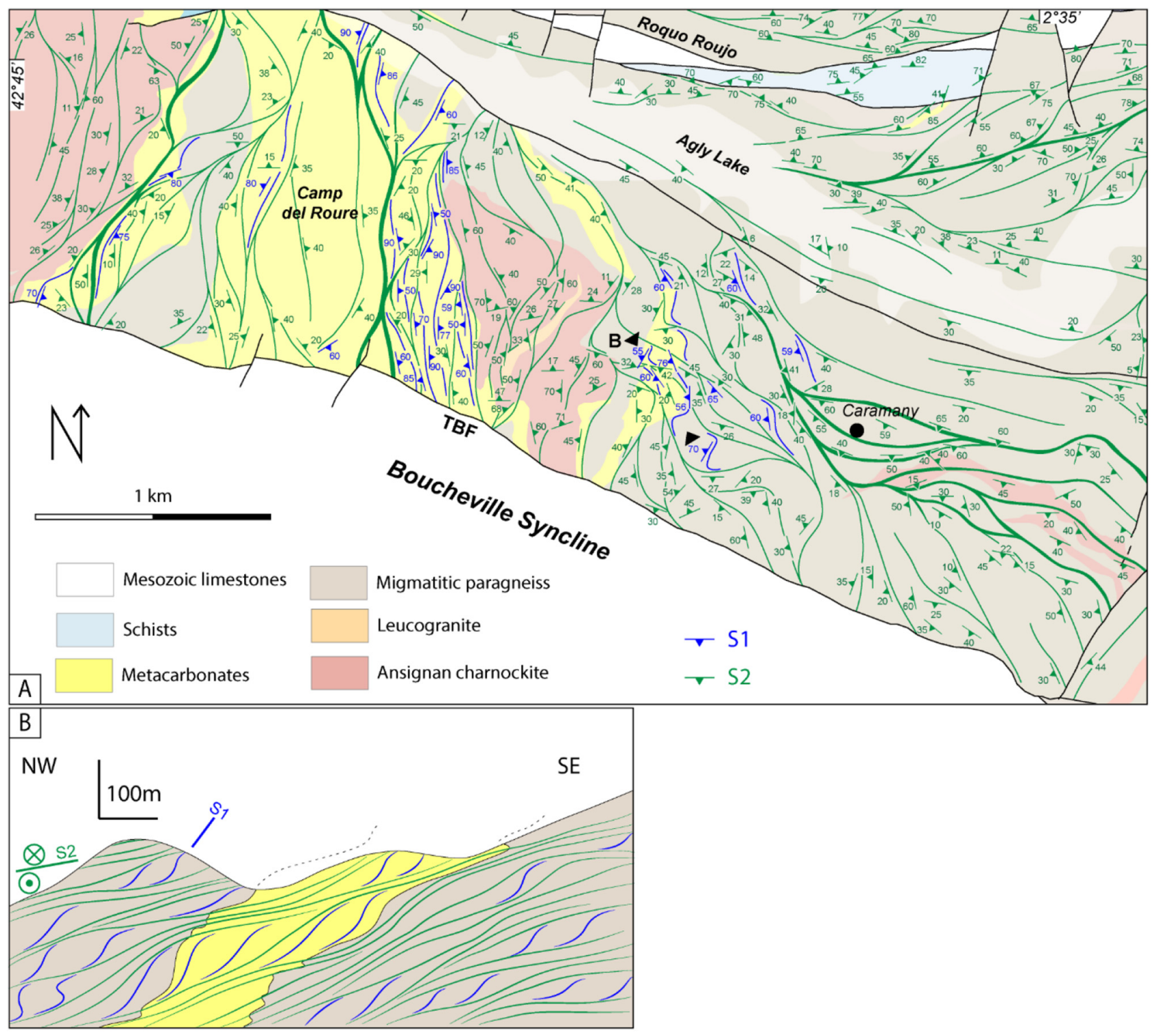

Fig. 7. Detailed structure of the southern part of the massif of the surroundings Caramany village. (A) Map of the foliations and their trajectories. (B) Cross-section.

A widening and intensification of D3 is observed from upper domain, i.e. LaTour-de-Fance area, toward the lower domain, i.e. Saint Martin village surroundings where all the planar fabrics transposed into S3

A vertical gradient of deformation is also observed in the TDZ. Indeed, D3 is more developed in the infrastructure in the western part of the massif than in the suprastructure in the eastern part. In the infrastructure between Ansignan and SaintMartin villages, all the planar fabrics are transposed into S3. In the upper structural levels of the suprastructure (i.e. Devonian marbles and Silurian schists), the D3 is less pervasive and form kilometer folds ( $c f$. next section). Along the TDZ south of the Tournefort diorite, D3 create a pinched synform that open as a fan-like structure to the east.

\subsection{D2/D3 interference in the Roque Courbe area}

North of Planèzes and Rasiguères villages, at the "Roque Courbe" area (literally "the curved rock" in English), the Devonian marbles and the Silurian-Ordovician schists present reversed polarity, with Ordovician schists on top of the Devonian marbles, observed on the southern side of the Roque Courbe near Planèzes and in the La Peyriere D3 Syncline (Fig. $15 \mathrm{~B}$ and $15 \mathrm{D}$ ). Relics of centimetre to decimetre synfolial F2 fold hinges are well preserved in the marbles (Fig. 6D). D2 deformation also resulted in the local boudinage of dolomitic layers of the Devonian marbles along a N-S trending direction, as well as shearing and thinning of the upper part of the metasedimentary pile resulting in a greatly reduced thickness 

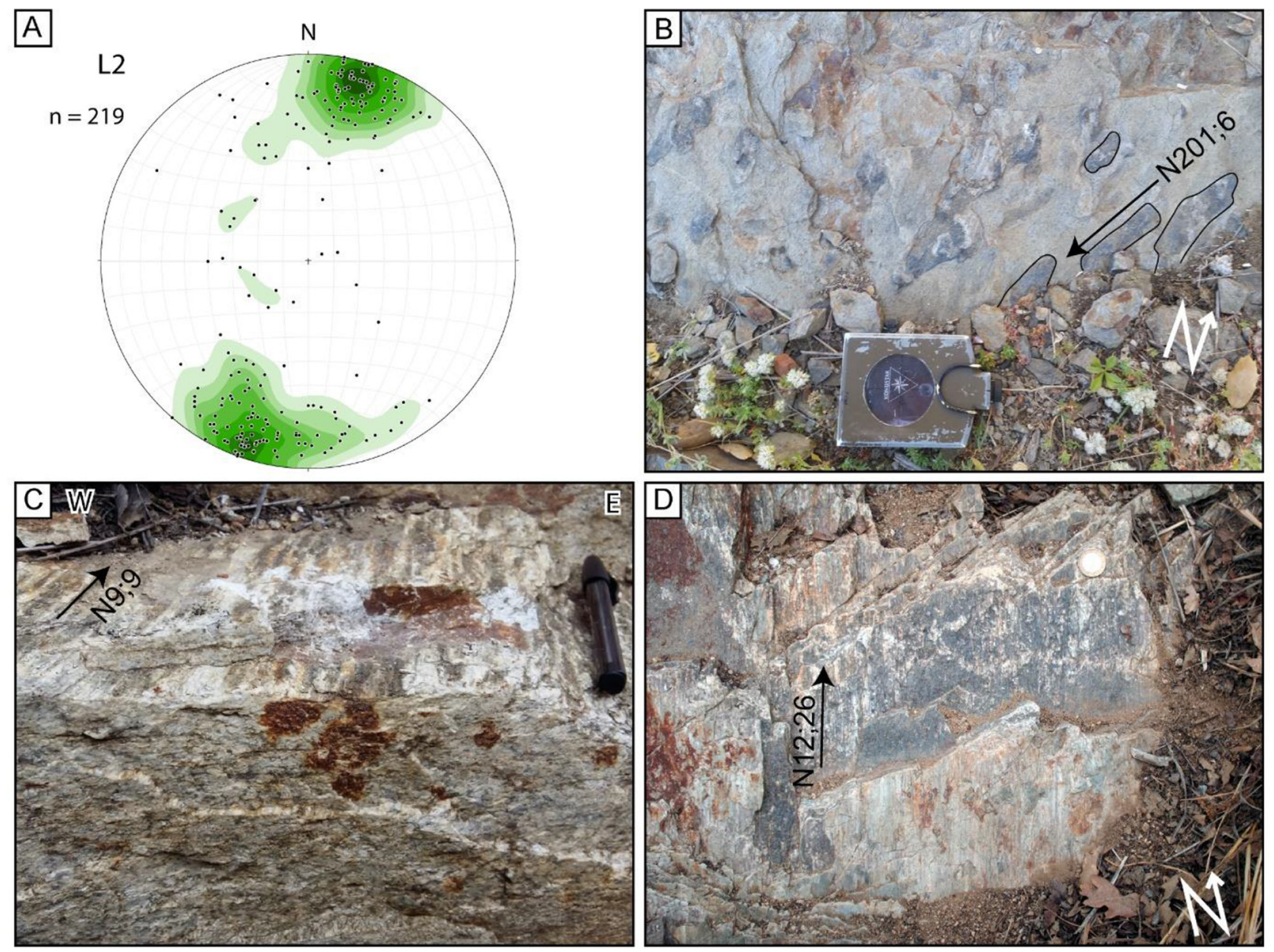

Fig. 8. Characteristics of the L2 stretching and mineral lineation. (A) L2 lineations plotted in lower hemisphere Wulf stereogram. (B) L2 marked by andalusites in micaschists. L2 in mylonitic paragneisses of (C) Caladroy and (D) Cuxous shear zones. Field measurements are given as N direction; plunge on the pictures.

of the sequence $(<20 \mathrm{~m})$ and the scarcity or even absence of the Silurian schist (see Berger et al., 1993). The Roque Courbe area first formed during D2 shearing with the development of a hectometer scale F2 isoclinal fold with a nearly horizontal axial plane and north trending fold axis by analogy with microstructural F2 axis. Early D2 isoclinal folding is responsible for the inverted polarity. Subsequently, F2 isoclinal fold was deformed by F3 open folds with ENE-WSW steeply dipping axial planes and axes gently to moderately plunging to the ENE. F3 folding resulted in the formation of the map-scale Rasiguères anticline and La Peyrière syncline (Fig. 15). D3 deformation resulted in the development of a vertical S3 axial plane cleavage best observed in the southern limb of the F3 "Rasigueres anticline" where the F2 hectometer fold hinges is observed and the tight "La Peyrière" syncline (Fig. 15). The Roque Courbe folded structure has been interpreted as due to Alpine tectonism (Delay, 1989) or as Variscan nappe stacking event (Berger et al., 1993; Fonteilles et al., 1993). We interpreted it as a kilometer scale D2/D3 fold interference pattern (Fig. 15).

\section{Deformation pattern in the late-Variscan magmatic intrusions}

\subsection{Ansignan charnockite and Cassagnes granites}

The Ansignan charnockite is emplaced in the deepest part of the Agly Massif at ca. $5 \pm 0.5 \mathrm{kbar}$ and $700-900{ }^{\circ} \mathrm{C}$ (Vielzeuf, 1984; Delay, 1989; Siron et al., 2012, 2020; Fig. 5). A magmatic foliation is defined by the preferential orientation of K-feldspar and a compositional banding corresponding to the alternation of charnockitic and leucogranitic magmas. This fabric parallels S2 foliation in the migmatitic paragneiss, arguing for syn-D2 emplacement, as already suggested in previous studies (Bouhallier et al., 1991; Berger et al., 1993; Althoff et al., 1994). Preferential alignment of K-feldspar porphyroblasts also defines a N-S trending lineation, consistent with the regional L2 stretching direction. The gabbro-norites enclaves contained in the Ansignan charnockite are mostly concordant with the S2 magmatic foliation (see Delay, 1989; Berger et al., 1993; Althoff et al., 1994) and stretched in some places toward a NE-SW 

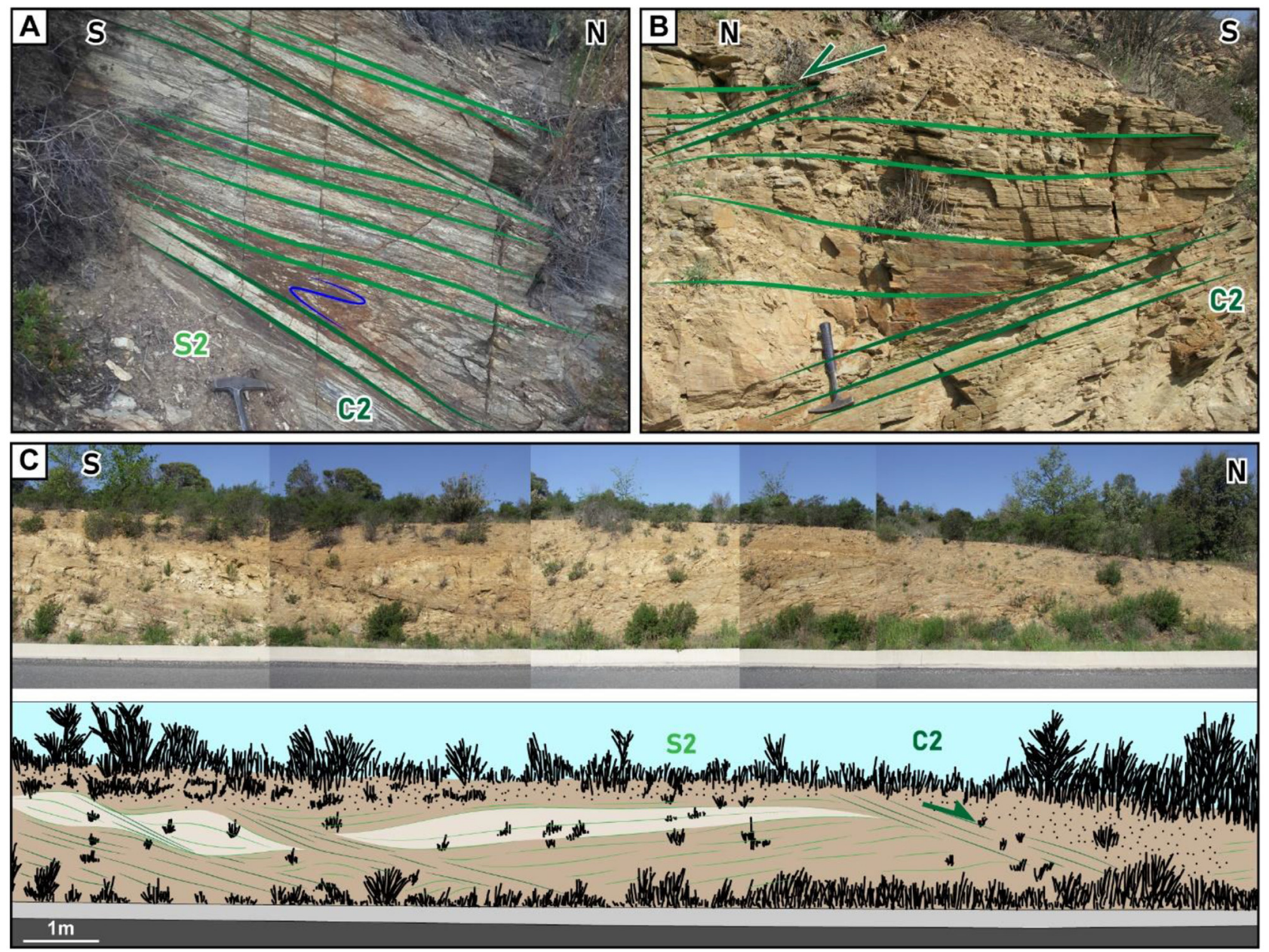

Fig. 9. C/CS relationships during D2 deformation with a top-to-the-north kinematics in paragneisses (A and C) and in micaschists (B).

direction. Deformation in the pluton was active from magmatic stage to sub-solidus conditions as attested by the injection of magma in small C2 shear bands, and by the solid state deformation of magmatic crystals like the development of quartz ribbons and the fracturation of K-feldspars. The Cassagnes granites show the same strain pattern as the Ansignan Charnockite, with a gently dipping S2 foliation and a N10N20 trending L2 mineral and stretching lineation. Like in the Ansignan laccolith, magmatic fabric is outlined by large $\mathrm{K}$ feldspar preferential orientation. However, D2 sub-solidus deformation is more intense in Cassagnes sills, resulting in the formation of elongated recrystallized K-feldspar and the recrystallisation of the matrix.

\subsection{The Tournefort / Saint-Arnac intrusion}

The Tournefort dioritic and Saint-Arnac granite intrusions belong to a same large plutonic complex that has been extensively studied from a chemical, structural and geochronological point of view by Olivier et al. (2004, 2008). The $\mathrm{Hbl}+\mathrm{Bt}+\mathrm{Pl} \pm \mathrm{Cpx}$ bearing Tournefort diorite is intrusive into the micaschists and anatectic gneisses (Delay, 1989; Figs. 3C, $11 \mathrm{C}$ and $13 \mathrm{~A}$ ). It is located in the TDZ and contains a weak but penetrative E-W to NE-SW vertical magmatic foliation with a near vertical lineation (Olivier et al., 2008 and Figs. 3C, 11C and 13A). The magmatic foliation is defined by the preferred alignment of biotite and hornblende and the compositional layering. Locally, the magmatic foliation is affected by localized, a few meters-wide vertical high strain zones developed under solid-state conditions (Fig. 13A). The magmatic and solid state deformation pattern is consistent with the D3 deformation.

As previously documented by Delay (1989) and Olivier et al. (2008), the Tournefort diorite intrusion induced a local partial melting of the surrounding micaschists that show F3 tight folds and an E-W S3 crenulation cleavage. Few tens of meters away from the diorite, contact metamorphism in the micaschists was also responsible for crystallization of andalusite preferentially oriented parallel to the S3 steep foliation. This suggest that diorite emplacement and associated contact metamorphism are contemporaneous with D3 deformation during development of the TDZ (Figs. 4, 13A and $13 \mathrm{~B})$. Nonetheless, the anatectic micaschists at the vicinity of the diorite do not have magmatic injections in their F3 axial planes, all the leucosomes are folded by the D3, which indicate that the D3 affecting the micaschists has occurred in subsolidus conditions. So, D3 may has been active at several stages from supra- to sub-solidus conditions. 

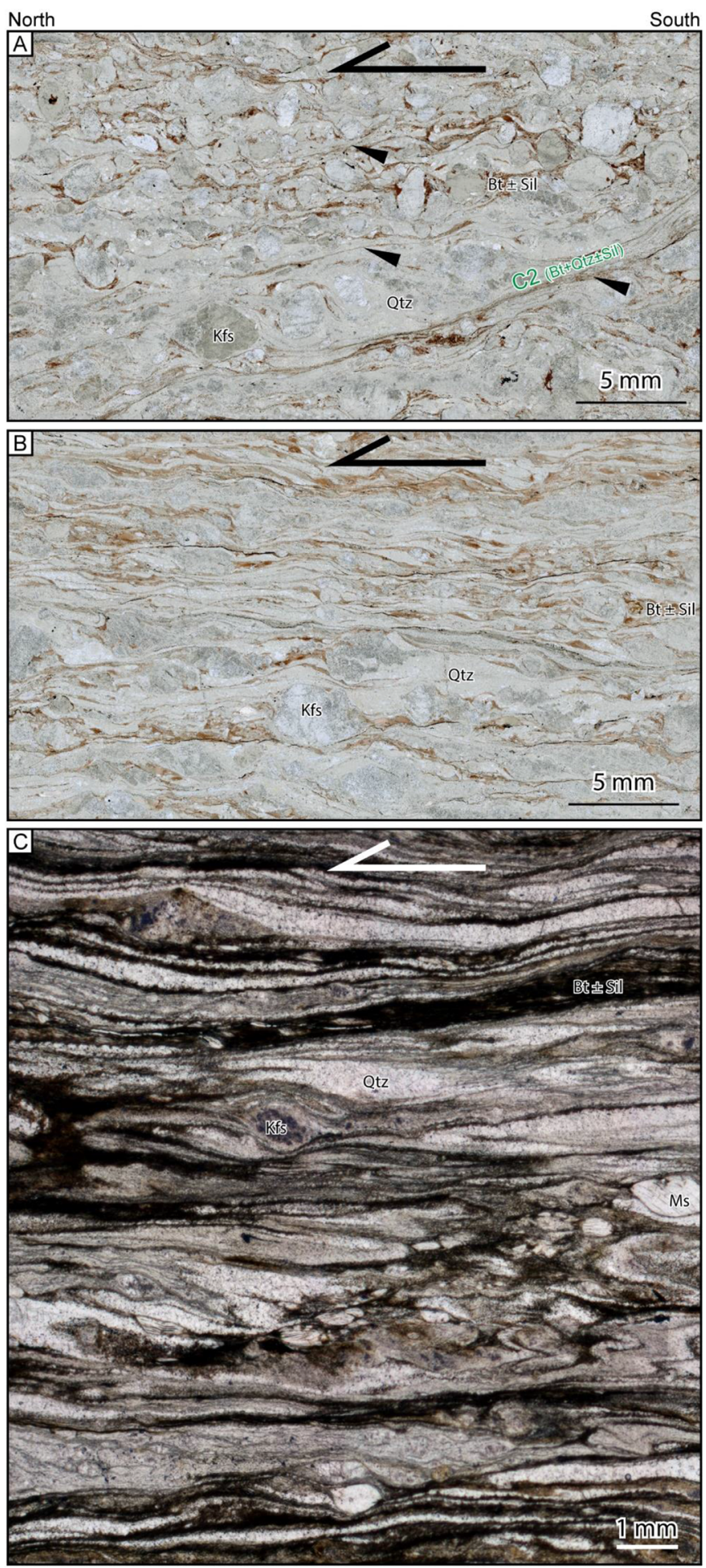

Fig. 10. Thin sections of a D2 strain gradient in paragneisses from the eastern part of the massif, close to Caladroy with a top-to-the-north kinematic. (A) low-strain deformation with local mylonites indicated by black arrows; (B) mylonitization generalized to the entire rock; (C) ultramylonitic texture with $\mathrm{Qtz}-\mathrm{Kfs}-\mathrm{Bt}-\mathrm{Sil}$ assemblages (polarized normal light).
The Saint-Arnac granite has a weak magmatic foliation marked by the preferred orientation of biotite and K-feldspar (Olivier et al., 2008). The pluton contains numerous meterscale xenoliths of micaschists and mafic enclaves oriented parallel to the foliation. In the western and southeastern parts of the pluton, xenoliths and mafic enclaves define an E-W trending and vertical foliation. The Saint-Arnac granite intrusion deforms and cross-cuts the M2 isograds (Fig. 2). It is also responsible for a weak contact metamorphism of the surrounding schists and micaschists with the crystallization of large muscovite flakes that are post-kinematic and secant on the S2 foliation (Delay, 1989; Berger et al., 1993). These observations indicate that the Saint-Arnac pluton is posterior to the M2 peak. In the northern part of the Agly massif, the huge amount of magma intruding the suprastructure is responsible for the deformation and the reorientation of S2 from a subhorizontal orientation to a NW-SE direction steeply dipping to the NE for several hundreds of meters (Figs. 13A and 13B; Delay, 1989). The schists and micaschists, located in the vicinity of the eastern margin of the pluton, are affected by a deformation D4, characterized by centimeterscale folds (F4) of S2 with NNE-SSW trending and steeply dipping axial planes. Fold hinges are vertical or steeply plunging toward the East. Locally, F4 folding is associated with the development of non-pervasive axial planar fabric S4 that is sub-vertical with a N20 azimuth, with no visible mineral or stretching lineation. The contact between the D4 and the D3 TDZ forms a triple point (Fig. 13A). Such deformations and reorientations of foliations have been described for several emplacements of Pyrenean plutons with dextral transcurrent settings (e.g. Gleizes et al., 1998b, 2001, 2006; Auréjac et al., 2004).

Based on Anisotropy of Magnetic Susceptibility (AMS) on the Saint-Arnac, Olivier et al. (2008) proposed that the pluton emplaced during a transpressive regime. This dextral transpression is documented in most of the pluton emplacements of the Axial Zone (Leblanc et al., 1993; Gleizes et al., 1998b, 2006; Olivier et al., 1999, 2016; Auréjac et al., 2004; Hilario Orús, 2004; Román-Berdiel et al., 2004, 2006; Antolín-Tomás et al., 2009; Izquierdo-Llavall et al., 2012), and also in two plutons of the NPZ (Lacourt: Gleizes et al., 1992; Pic des Trois-Seigneurs: Leblanc et al., 1996). Based on these observations and studies, some intrusions of the Saint-Arnac pluton may have took place during a dextral transcurrent setting, which may correspond to the D3. Nonetheless, the AMS lineations in the northern part of the pluton are N20, which may indicate an emplacement synchronous with the D2.

\subsection{The garnet-bearing leucogranites}

A third type of magmatic intrusion is represented by garnet-bearing leucogranites that form sills and dykes a few centimeters to tens meters in width. Of particular interest are the leucogranite dyke that crops out east of the Saint-Arnac intrusion (Fig. 13A) and the leucogranite pluton south of Latour-de France village (Fig. 14A). In both localities, the leucogranites are composed of quartz, alkali feldspar, 


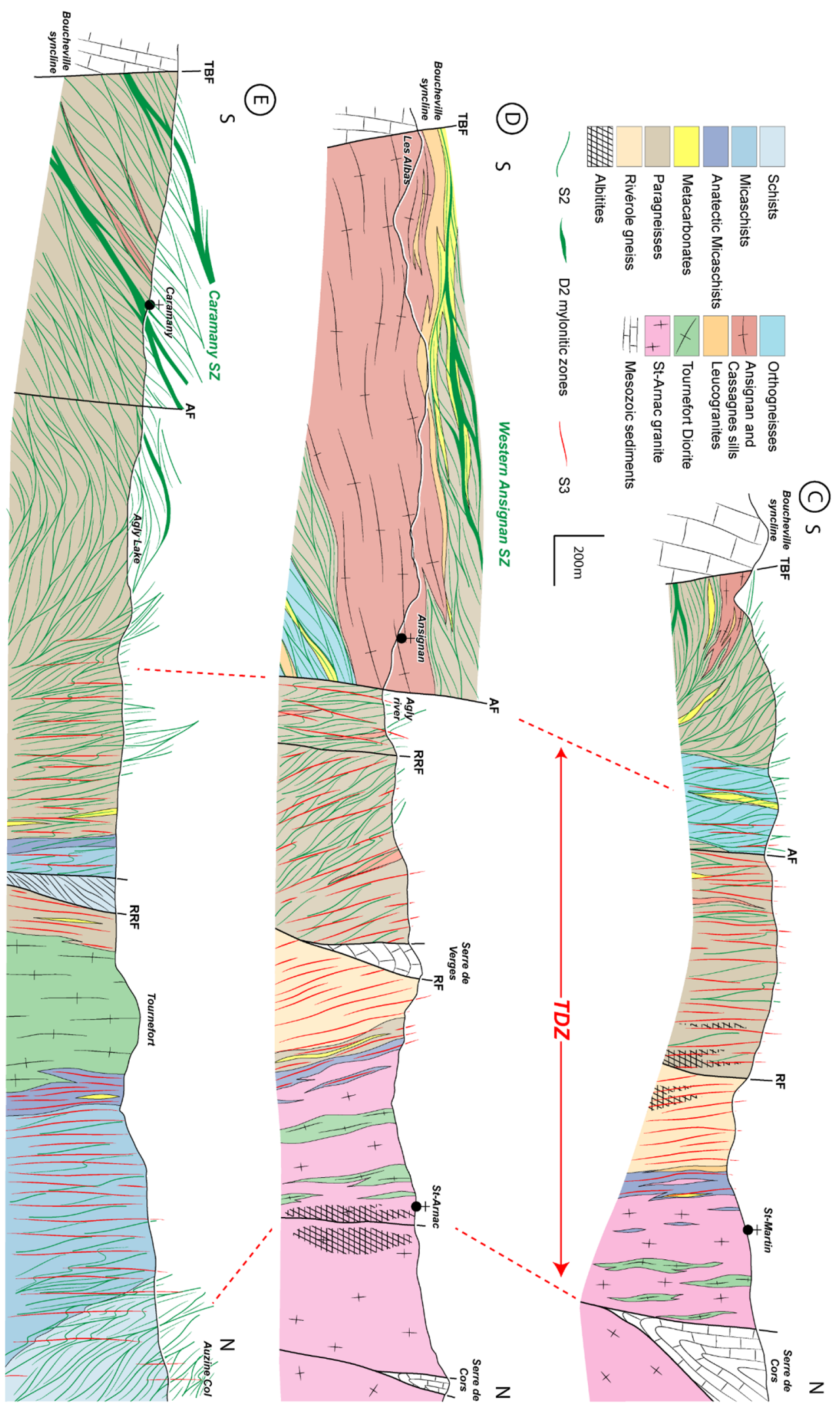

Fig. 11. N-S cross-sections through the Agly Massif. (C) Western part of the massif. (D) Cross-section through Ansignan charnockite and Serre de Vergès with pinched Mesozoic rocks. (E) Cross-section through the Tournefort Diorite. TDZ: Tournefort Deformation Zone. 

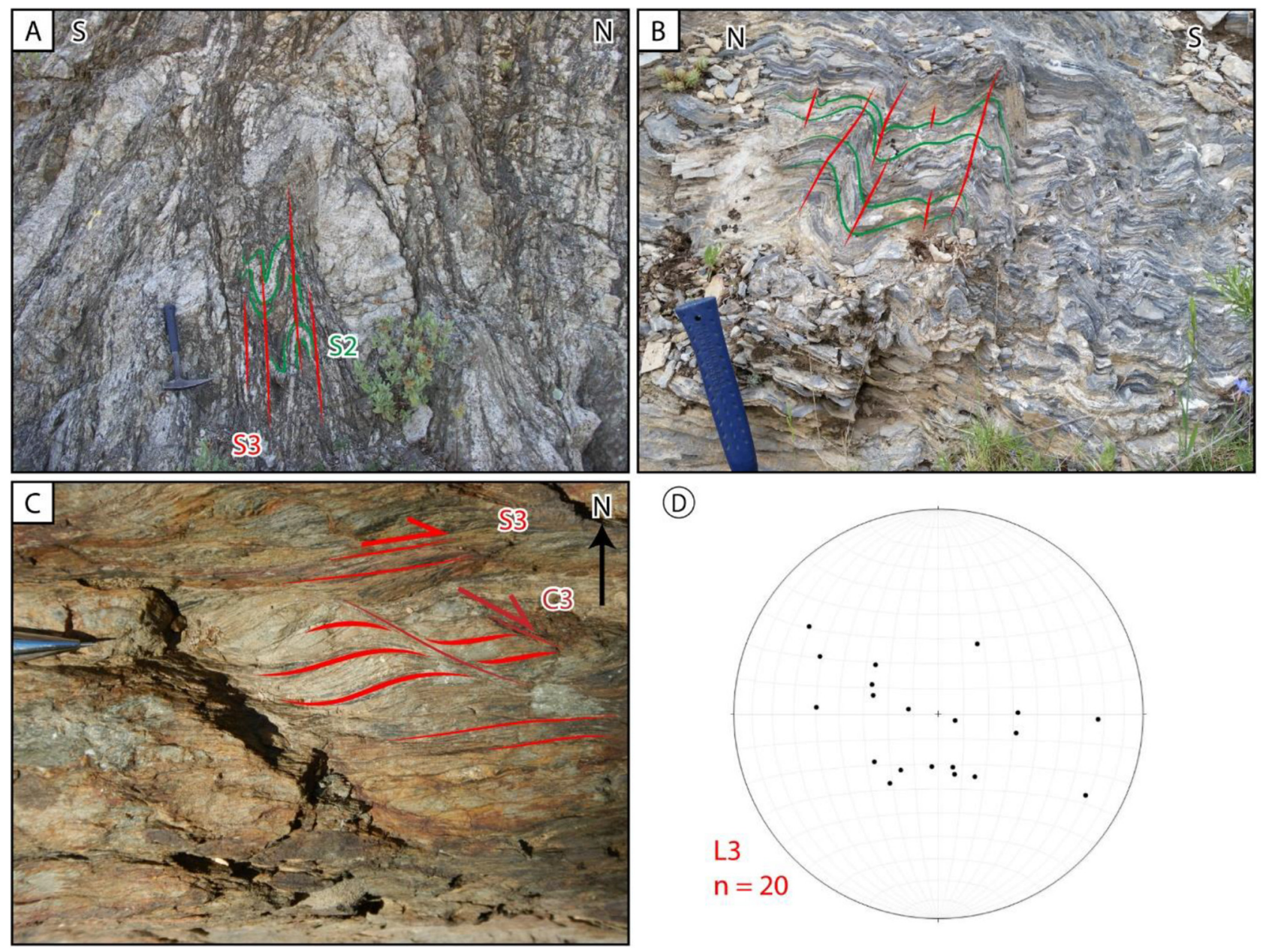

Fig. 12. D3 deformation structures. F3 folds in (A) paragneisses and (B) Devonian "calc-schist" marbles. (C) Dextral Kinematics in micaschists with $\mathrm{C} / \mathrm{S}$ structures relationships. (D) L3 lineations plotted in lower hemisphere Wulf stereogram.

plagioclase, biotite, muscovite and garnet. The east SaintArnac dyke cuts accross the S2-S3 foliations and post-date early D3 deformation (Fig. 13A). The Latour-de-France leucogranite is located in a D3 fold hinge (Fig. 14A) and does not show visible solid-state deformation. But, microstructures like microfractures in feldspar megacrysts infilled by quartz, replacement of K-feldspar margins by myrmekites, and plastic deformation of quartz with chessboard extinction suggest that the leucogranite was deformed under high temperature submagmatic conditions (Marmo, 1971; Hibbard, 1987; Vernon, 1991, 2000; Bouchez et al., 1992, 2006; Pawley and Collins, 2002). We suggest that the Latour-de-France garnet-bearing leucogranite emplaced after D2 deformation, probably during the final stage of the D3 deformation.

\subsection{Pegmatites}

Abundant pegmatites are observed from the top of the migmatitic gneisses to the cordierite-bearing Ordovician micaschists. Pegmatites form both concordant and discordant dykes and lense-shaped bodies ranging in size from a few decimeters up to several 10 meters. These bodies are interpreted to be the result of the ascent of residual hydrous silicate melt coming from the crystallization of the anatectic melt of the migmatitic infrastructure. The pegmatite mineralogical assemblage is made of $\mathrm{Qtz}+\mathrm{Kfs}+\mathrm{Pl}+\mathrm{Ms} \pm \mathrm{Bt} \pm \mathrm{Tur}$. Some pegmatites cross-cut the S2 foliation and are undeformed whereas others are boudinaged in D2 mylonitic fabrics. Mutually cross-cutting relationships between pegmatites and S2, and N20 stretching lineations in the D2 mylonites suggest a syn- to late-D2 age for the pegmatite emplacement.

\section{Discussion}

\subsection{Impact of the Cretaceous thinning and Alpine tectonic on the Agly massif gneissic basement.}

The Agly massif belongs to the North Pyrenean Zone (NPZ) that has been recently interpreted as an analogue of modern passive margin (Lagabrielle and Bodinier, 2008; Jammes et al., 2009; Debroas et al., 2010; Lagabrielle et al., 2010; Clerc, 2012; Clerc et al., 2012, 2013; Masini et al., 2014). This tectono-metamorphic model is supported by a HT/ LP metamorphism recorded in the Mesozoic sediments reaching up to $550^{\circ} \mathrm{C}$ in the eastern Pyrenees within inverted E-W trending basins (Boucheville and Bas-Agly synclines, Fig. 1). This high-grade metamorphism is proposed to be 


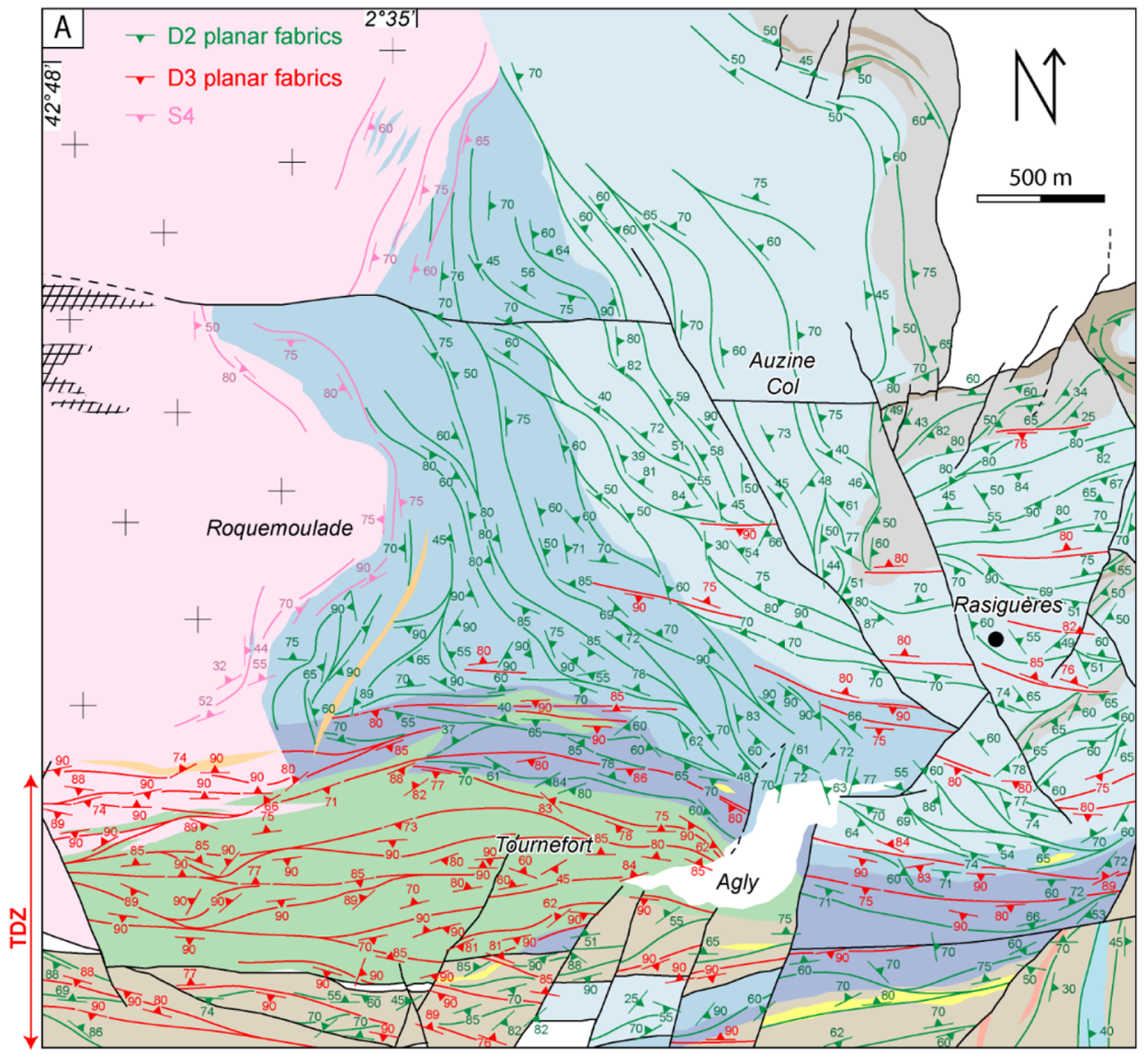

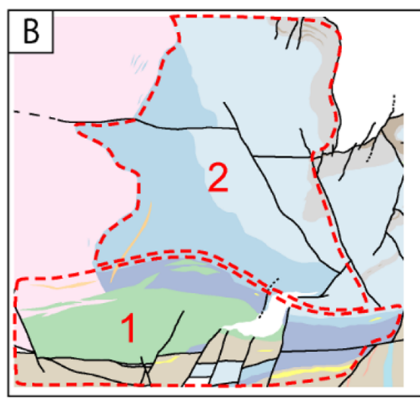

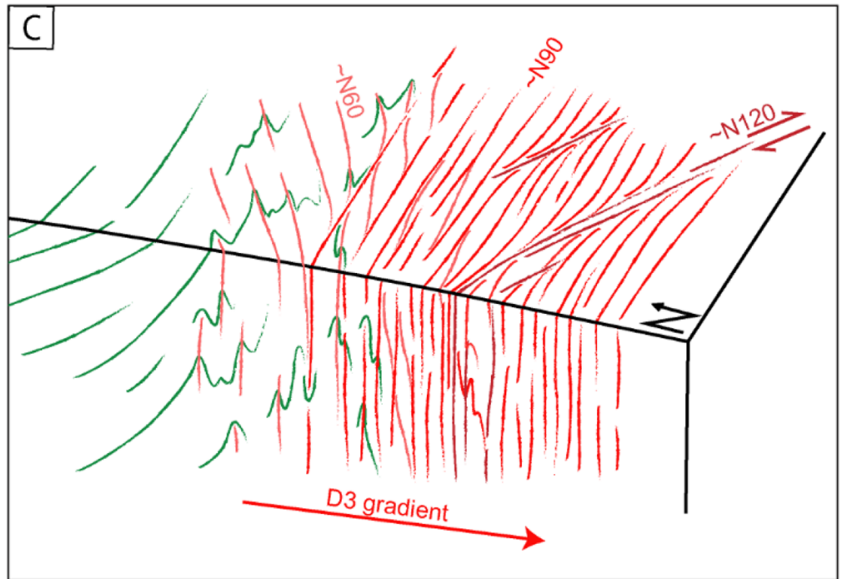

1. Foliations in the TDZ

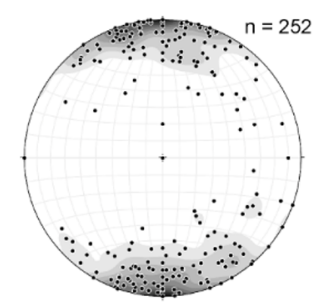

2. Eastern margin of St-Arnac granite

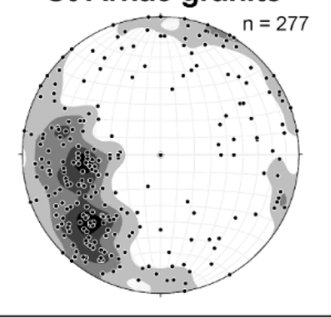

Mesozoic and Quaternary Devonian marbles Silurian schists Schists Micaschists Anatectic micaschists Metacarbonates Paragneiss Orthogneiss Cassagnes sills Tournefort diorite St-Arnac granite Leucogranite

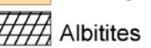

Fig. 13. Detailed structure of the eastern margin of Saint-Arnac granite with: (A) map of the foliations and their trajectories. (B) Poles of undifferentiated planar fabrics (lower hemisphere Wulf net) of the TDZ and of the eastern margin of Saint-Arnac granite. (F) Sketch of the deformation gradient of the TDZ. 

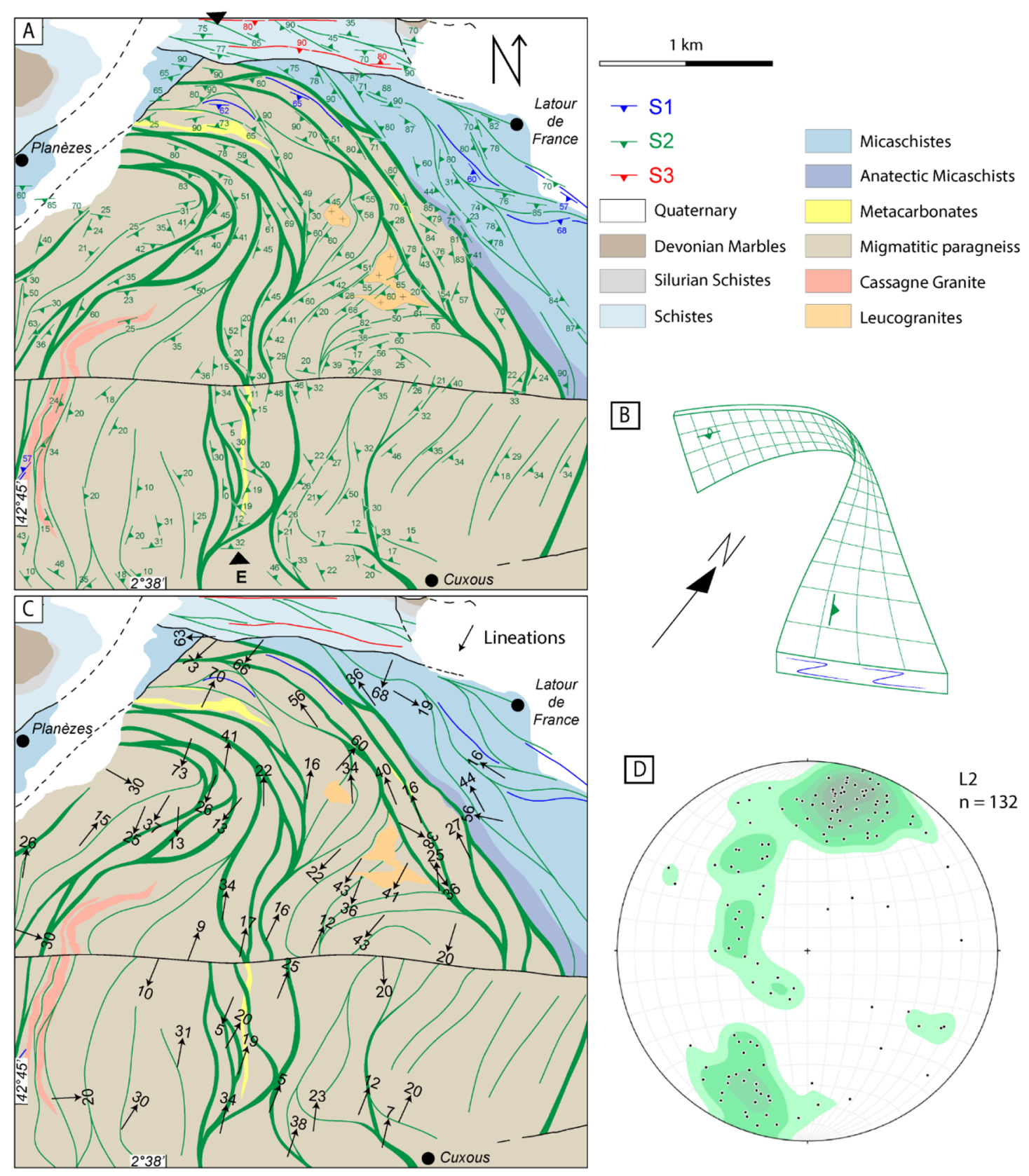

B
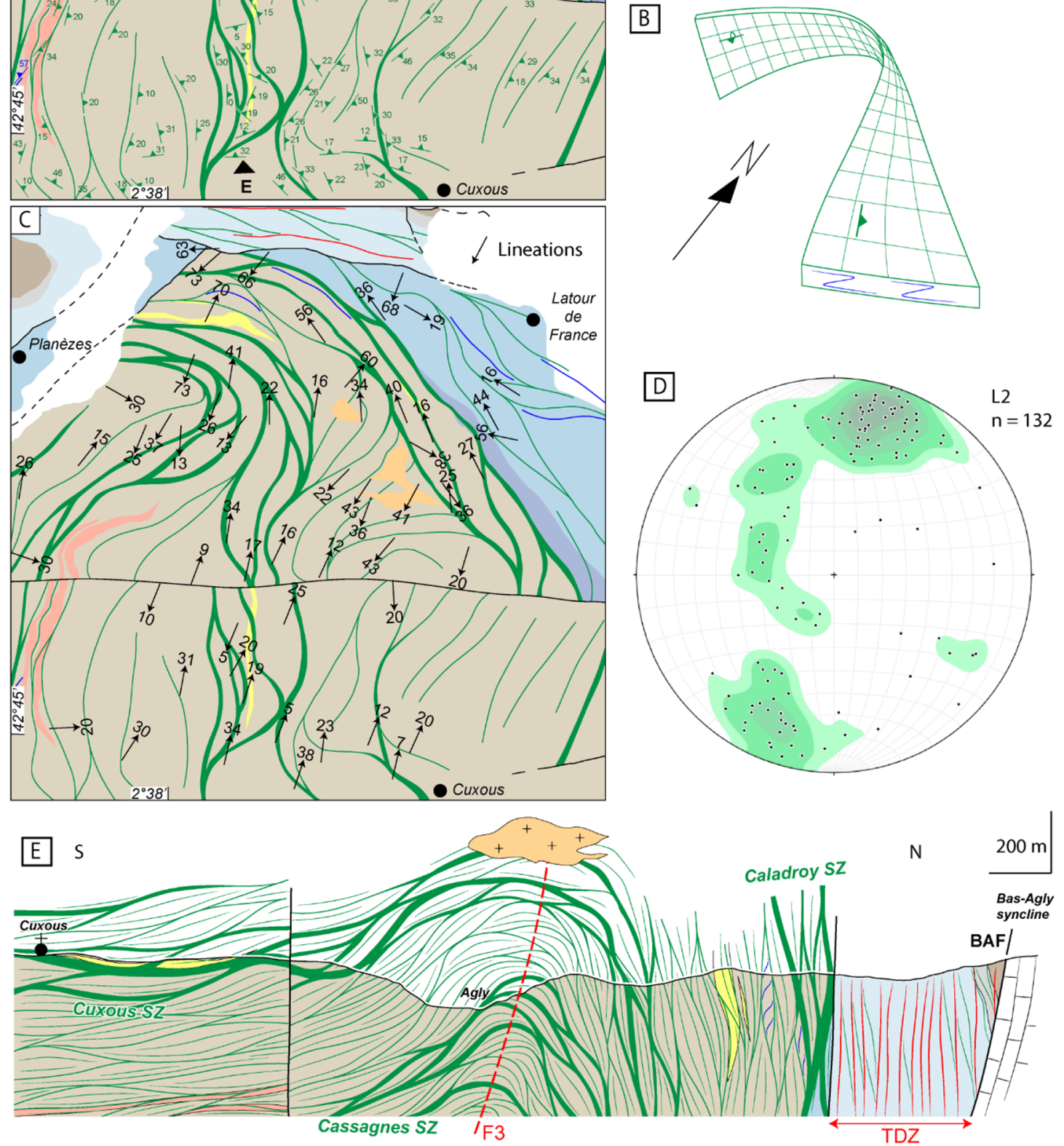

Fig. 14. Detailed structure of the northeastern part of the massif in Latour-de-France area. (A) Map of the foliations and their trajectories. (B) 3D sketch of the general S2 foliation shape. (C) Map of the L2 lineations and (D) L2 stereogram of the area. (E) N-S cross-section through the Latour-de-France structure showing S2/S3 relationships. They line up on a stereogram and indicate an E-W trending axis fold plunging towards the East. 

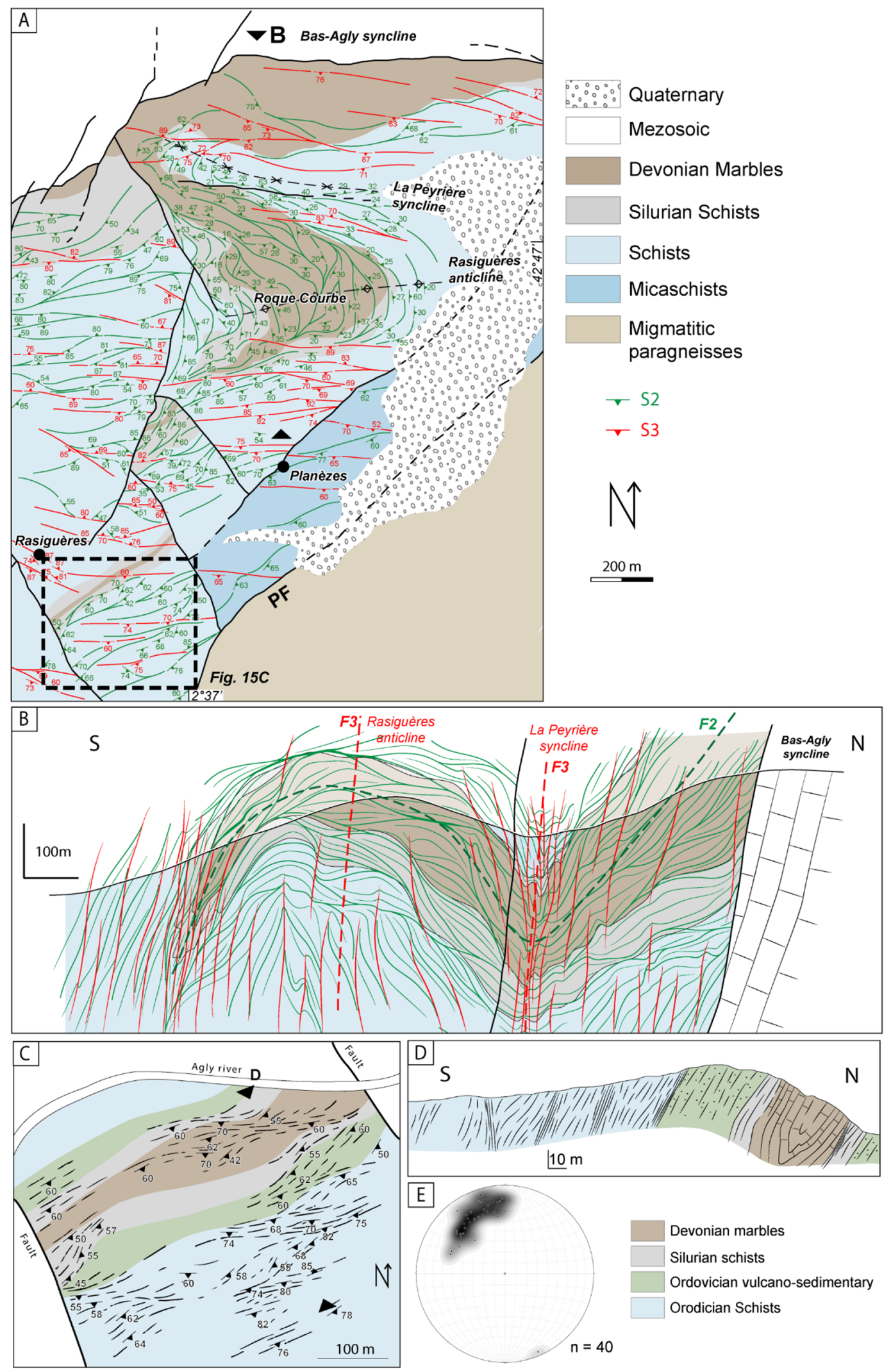

Fig. 15. (A) Map of S2 and S3 foliations in the Roque Courbe area. (B) N-S cross-section through the Roque Courbe showing S2/S3 relationships. (C) Detailed area located on map (A), illustrating the different directions of planar fabrics in the TDZ. (D) Cross-section through map (C) showing the isoclinal F2 fold in the Devonian marbles. (E) Poles of undifferentiated planar fabrics plotted in lower hemisphere Wulf stereograms of map (C). 
associated with significant Cretaceous crustal thinning, locally reaching to unroofing of subcontinental mantle (Clerc et al., 2015). South of the AM, this HT/LP Pyrenean event related to crustal thinning was strong enough to imply partial melting of the crustal rocks below the Boucheville basin (Chelalou et al., 2016). A reasonable question arises about the thermomechanical impact of Cretaceous extensional tectonic and metamorphism on the Variscan basement within the Agly massif. Some localized mylonites within the gneissic basement were considered as Cretaceous (Paquet and Mansy, 1991; Vauchez et al., 2013). Apatite U-Pb results yield Odlum and Stockli (2019) to propose the existence of a high temperature shear zone located below the Saint-Arnac pluton that was responsible for (1) the Cretaceous thinning during crustal scale boudinage and necking of the continental crust, and (2) the present-day apparent high temperature gradient within the AM. In agreement with Bouhallier et al. (1991) our field observations demonstrate that extensional deformation occurred together with Variscan migmatization and granitoid intrusions that gave ages at ca. $307 \mathrm{Ma}$ (Tournaire Guille et al., 2018). The emplacement of the Saint-Arnac pluton at $304 \pm 5 \mathrm{Ma}$ (Olivier et al., 2008) led to the local re-orientation of S2 in the micaschists and induced a contact metamorphism cutting the M2 isograds (Fonteilles et al., 1993; Olivier et al., 2008).

Following Corre et al. (2018), we suggest that the Cretaceous rifting leading to the strong thinning of the continental crust and unroofing of subcontinental mantle is restricted to the bottom of the Cretaceous basins and did not affect the Variscan basement that crop out in the Agly massif. Recent thermochronological and RSCM studies reported that the Cretaceous temperatures measured in the Agly Paleozoic rocks did not exceed $450{ }^{\circ} \mathrm{C}$ and could not account for the HTLP mineralogical assemblages induced by the M2 metamorphism in the Agly gneisses (Boulvais, 2016; Ducoux, 2017; Ternois et al., 2019). Hydrothermal fluid circulations in the basement, without clear evidence of metasomatic alteration, is also expected and may have been at the origin of the complete or partial resetting of the isotopic U-Th- $\mathrm{Pb}$ systems of monazite and apatite observed in the gneiss from the southern part of the Agly massif, close to the Boucheville bassin (Odlum and Stockli, 2019).

\subsection{Reappraisal of the Variscan structure of the Agly massif}

The Variscan basement of the Agly Massif is commonly described by a single foliation envelope that draws a half-dome structure (e.g. Delay, 1989; Olivier et al., 2004; Tournaire Guille et al., 2018). Conversely, we propose that the AM resulted from the superimposition of three deformations D1, D2 and D3 that corresponded to crustal thickening, extensional orogenic collapse and late-transpression, respectively.

In the Variscan massifs of the Pyrenees, relics of early barrovian metamorphic conditions have been documented (Fonteilles et al., 1964; Besson, 1974; Roux, 1977; Azambre and Ravier, 1978; Vielzeuf, 1980; Vielzeuf, 1984; Ayora et al., 1993; Azambre and Guitard, 2001; de Hoÿm de Marien et al., 2018) that might be related to crustal thickening (Bouhallier et al., 1991; Carreras and Capella, 1994; Matte, 2002; Vilà et al., 2007; Denèle et al., 2009, 2014; Laumonier et al., 2010; Aguilar et al., 2015). In the Agly massif, we document a D1 deformation event characterized by $\mathrm{a} \sim \mathrm{N}-\mathrm{S}$ striking and moderately dipping S1 foliation. The steeply dipping S1 may account for an early period of crustal contraction. Mineral assemblages observed within D1 fabrics do not allow us to distinguish the M1 metamorphism from the M2 high-grade metamorphism. The description of relics of kyanite in the Agly massif by Fonteilles (1970) and Fonteilles and Guitard (1971) led us to speculate that the Agly might have been affected by a slight crustal thickening during D1 crustal contraction. An early planar fabric with the same orientation as the $\mathrm{S} 1$ is documented in the Cap de Creus and is also attributed to a crustal thickening stage (Druguet, 1997, 2001).

Ages reported for the D1 crustal thickening range between 340-320 Ma. Mezger and Gerdes (2016) obtained ages of ca. 339-337 Ma from the Soulcem and Bossost plutons interpreted to date the thickening stage. Denèle et al. (2014) proposed an age for D1 thickening between 323 and $308 \mathrm{Ma}$ based on a synthesis of the previous works on the Axial Zone. Lemirre (2016) obtained several dates around $320 \mathrm{Ma}$ from the NPZ (Castillon and Bessède massifs) and proposed to link them to the early crustal thickening.

The main deformation in the Agly massif is recorded by the development of a shallowly dipping S2 foliation with a conspicuous $\mathrm{N} 20^{\circ} \mathrm{E}$ directed stretching lineation and dominant top-to-the-north normal shearing. The D2 deformation reworked an early S1 foliation preserved in D2 low strain zones. This results in the N-S trending kilometer-scale undulation observed along an E-W profile, in response of the superimposition of D1 and D2 rather than folding of a single low-dipping (S2) foliation as previously documented (Delay, 1989; Berger et al., 1993; Tournaire Guille et al., 2018).

In the infrastructure, the high temperature conditions $\left(\mathrm{T}>550^{\circ} \mathrm{C}\right)$ of the $\mathrm{D} 2$ deformation is attested by the synkinematic mineralogical assemblage quartz-biotite-sillimanite observed in D2 mylonitic to ultramylonitic normal shear zones in gneisses (Paquet and Delay, 1989; Siron et al., 2012, 2020) and by the magmatic state to solid state of D2 in the Ansignan charnockite (Althoff et al., 1994). The S2 foliations are parallel to the HT-LP metamorphic isograds and to the migmatitic layering, and the L2 is outlined by preferential alignment of minerals of this HT-LP metamorphism (Fig. 7). These observations indicate that D2 shearing developed from peak metamorphism (under suprasolidus conditions) toward subsolidus amphibolite facies conditions along a retrograde P-T evolution as previously observed in the Saint Barthélémy massif (de Saint Blanquat et al., 1990).

These D2 high strain zones are responsible for the significant thinning of the massif and the juxtaposition of different structural levels along main high-strain zones, like the Caladroy SZ at the interface between the infra- and suprastructure (This study, Delay, 1989; Bouhallier et al., 1991; Siron et al., 2012, 2020) and the Cuxous, Cassagnes, East and West Ansignan shear zones in the partially molten infrastructure (This study, Delay, 1989; Paquet and Mansy, 1991; Siron et al., 2012, 2020). We did not observe the bottom boundary of the S2 domain and it is likely that D2 thinning continues downward in the lower structural level. The D2 deformation represents a wide zone of ductile thinning that spreads out over 
the whole tectonic pile. A significant part of the thinning is likely to have been accommodated during retrograde cooling along numerous smaller $\mathrm{C} 2$ shear zones.

Timing of D2 is constrained by geochronological data obtained on syn-D2 migmatites and granitoids. Siron et al. (2012, 2020) reported LA-ICP-MS U-Pb monazite ages at $305 \pm 4 \mathrm{Ma}$ and $306 \pm 2 \mathrm{Ma}$ attributed to peak-metamorphic conditions. Tournaire Guille et al. (2018) give an age at $299 \pm 4$ Ma that may represent the crystallization of migmatitic melt. The Ansignan charnockite gave LA-ICP-MS U-Pb ages and ID-TIMS ages that range in between ca. 315 and 300 (Postaire, 1982; Respaut and Lancelot, 1983; Tournaire Guille et al., 2018). The syn-D2 Cassagnes granite is dated at $308 \pm 3 \mathrm{Ma}$ (Tournaire Guille et al., 2018). All these geochronological data are consistent and argue for D2 deformation at suprasolidus conditions in the range 315$300 \mathrm{Ma}$. Siron et al. $(2012,2020)$ constrain the cooling history between 300 and $296 \mathrm{Ma}$.

In the northern part of the Agly Massif and along the southern boundary of the St-Arnac-Tournefort plutonic body the foliation is steeply dipping. Paquet and Mansy (1992) attributed this northern steepening to Alpine collision whereas Olivier et al. $(2004,2008)$ argued for a $45^{\circ}$ tilt toward north of the northern part of the Agly massif in response of the Cretaceous rifting and formation of tilted blocks during extension tectonics. The hypothesis of Alpine or Cretaceous tectonics as partially or totally responsible for the steepening of the foliations in the northern Agly (Paquet and Mansy, 1992; Olivier et al., 2004, 2008) is inconsistent with our structural results. The vertical domain corresponds to an E-W trending transpressional strike-slip shear zone (TDZ) responsible for the folding and steepening of the previous D1/D2 structures. At the western part of the AM, i.e. the deepest structural level, the D3 is several kilometers wide. At the eastern part, i.e. upper structural levels of the suprastrucutre, D3 localizes as a pinched synform. In the Agly massif, the TDZ shows both shallowly- and steeply-plunging lineations that are a common feature of transpressional shear zones (Fossen and Tikoff, 1993; Tikoff and Teyssier, 1994; Greene and Schweickert, 1995; Tikoff and Greene, 1997). Emplacement of Saint-Arnac and Tournefort plutons may have occasioned a N-S directed shortening inducing a pure-shear component of transpression into the TDZ during D3 dextral shearing with both subhorizontal and subvertical stretching L3 lineations. The TDZ is intruded by the syn-D3 Tournefort diorite dated at $307 \pm 1 \mathrm{Ma}$ and $308 \pm 1 \mathrm{Ma}$ (Olivier et al., 2004, 2008). This age may constitute a lower boundary for the timing D3 ductile shearing. Since it reworked the D2 mylonites, the D3 transpression was still active after $295 \mathrm{Ma}$.

\subsection{Comparison with the surrounding Variscan massifs}

The relative position of the Agly massif in relation to the Pyrenean Axial Zone and the French massif central mainly depends on the movements attributed to the NPF that are debated (e.g. Olivet, 1996; Sibuet et al., 2004; Jammes et al., 2009; Carreras and Druguet, 2014; Tugend et al., 2015). Regardless of the amount of displacement of Iberia, the AM is located north of the NPF and should share more features with the NPZ and Montagne Noire massifs (Burg et al., 1994) than with the Axial Zone. In the Western European Variscides, lateCarboniferous to early-Permian extension is mainly N-S directed north of the NPF whereas it is E-W trending, i.e. nearly parallel to the belt in the Pyrenean Axial Zone (Burg et al., 1994; Cochelin et al., 2017). Also, at this time, dextral strike-slip tectonic, widely documented in the internal and external zones of the Variscan orogen (e.g. Edel et al., 2018), has largely contributed to the flow of the thickened Variscan crust and was still active during extensional collapse (Burg et al., 1994, Gébelin et al., 2007, 2009). As proposed by Cochelin (2016), the NPMs are comparable to the southern part of the Central Massif and to the Montagne Noire, where an extensional setting is described with a main N-S kinematics (Van Den Driessche and Brun, 1992; Burg and Vanderhaeghe, 1993; Faure, 1995; Faure et al., 2009; Pitra et al., 2012; Barbey et al., 2015), coeval with HT-LP metamorphism and magmatism between 305 and $295 \mathrm{Ma}$ (Pitra et al., 2012; Couzinié et al., 2016; Barbey et al., 2015). Transtensional and extensional settings are dominant in the NPZ (Thiébaut, 1964; Roux, 1977; de Saint Blanquat, 1989, 1993; de Saint Blanquat et al., 1990; this study). In the St-Barthélémy massif (NPZ), Variscan mylonitization evolved from HT to LT conditions and is responsible for several kilometers of crustal thinning (de Saint Blanquat, 1989, 1993; de Saint Blanquat et al., 1990; Delaperrière et al., 1994).

In the Montagne Noire (southern French massif central), the finite strain pattern is the result of a D2 dextral strike-slip shearing in the infrastructure, coeval with D3 extensional collapse localized along the anatectic front between 315 and $295 \mathrm{Ma}$ (Pitra et al., 2012; Rabin et al., 2015; Roger et al., 2015; Trap et al., 2017). The HT-LP metamorphism reaches $700{ }^{\circ} \mathrm{C}$ at $0.35 \mathrm{GPa}$ (Rabin et al., 2015; Fréville et al., 2016) and is contemporaneous with a main partial melting and magmatic event dated at ca. 310-300 Ma (Roger et al., 2015; Trap et al., 2017). Poujol et al. (2017) have also found ages at $320 \mathrm{Ma}$ and attributed it to another partial melting event. This ancient partial melting event could be linked and compared to the ages of Lemirre (2016) at $320 \mathrm{Ma}$ in the NPMs.

Looking at the Agly massif and the Pyrenean Axial Zone, the metamorphism is very similar in both domains, with HT-LP metamorphic gradients between 60 and $80^{\circ} \mathrm{C} / \mathrm{km}$ in the suprastructure, and near isothermal gradients in the infrastructure (Siron et al., 2012, 2020; Lemirre, 2016). Temperatures are slightly higher in the Agly massif and the NPZ than in the Axial Zone, $800-850{ }^{\circ} \mathrm{C}$ and $700-750{ }^{\circ} \mathrm{C}$ respectively (Lemirre, 2016). The metamorphism and the magmatism ages are similar with estimations that range between ca. 305 and $275 \mathrm{Ma}$ in the NPZ (Hart et al., 2016; Lemirre, 2016) and at ca. 315-295 Ma in the Axial Zone (Denèle et al., 2014; Druguet et al., 2014). In the Variscan Eastern Pyrenees, the peak of magmatic activity is well constrained around $306 \mathrm{Ma}$ (Denèle et al., 2014).

The main difference between the NPZ and the Axial Zone lays on geometrical and kinematics aspects. In the Axial Zone, the lineations are predominantly parallel to the belt elongation and the regional finite strain pattern defines a dextral transpression (e.g. Soliva, 1992; Gleizes et al., 1997, 1998a, 2001; Olivier et al., 1999, 2016; Román-Berdiel et al., 2004, 2006; Denèle et al., 2009, 2014; Carreras and Druguet, 2014; Cochelin et al., 2017). Dextral transpression in the Axial Zone 
is interpreted as the result of lateral escape of the partially molten crust during closure of the Iberian-Armorican syntax between ca. 305 and $295 \mathrm{Ma}$ (Denèle et al., 2009; Cochelin et al., 2017). Although transpressive tectonics is preponderant in the Axial Zone, some studies reported late-Carboniferous thinning with a N-S to NE-SW direction synchronous with late Carboniferous granodiorite pluton emplaced at 305-310 Ma (Bouchez and Gleizes, 1995, Casas et al., 2007),

In the NPZ stretching lineations are mostly transversal and strain pattern is related to an extensional setting (Bouhallier et al., 1991; de Saint Blanquat, 1993; Cochelin, 2016; this study). However, some studies proposed that the eastern NPM and Axial Zone shared the same transpressional tectonic event at the end of the Variscan orogeny with partitioning into domains of localized dextral strike-slip shear zones (Carreras and Druguet, 2014). In the Trois-Seigneurs and St-Barthelemy massifs of the NPZ, few localized strike-slip shear zones are attributed to a late wrench-dominated transpression developed under retrograde metamorphic conditions (Carreras and Druguet, 2014).

The Agly massif and the eastern Axial Zone share the same strain pattern with pinched synforms surrounding wide domes, sheet-shaped plutons along the infrastructure/suprastructure interface that are lately affected by transpression. Carreras and Druguet (2014) proposed that the Agly, Mouthoumet and Montagne Noire massifs shared the same compressiondominated transpression as documented in the Axial Zone.

\subsection{Late-Variscan tectonic evolution of the Agly massif}

In the following, we propose a tectonic model for the middle-Carboniferous to early-Permian evolution of the Agly massif late-Varsican crust that describes the progressive switch from gravitational collapse to dextral transpression in a synplate convergence context.

The initial stage of our conceptual model is a thickened orogenic crust corresponding to a portion of the external part of an orogenic plateau that has reached a critical thickness. Regardless of the ante-D2 attitude of S1 that remains unknown, D1 upright folding and a steeply dipping S1 foliation featured the crust before ca. $315 \mathrm{Ma}$ and set up the initial conditions for the development of the Agly massif (Fig. 16A). Subsequently to thermal relaxation of the thickened crust, the middle crust reached partial melting conditions and started to flow in response to gravitational gradients. Vertical shortening and S2 foliation may have been initiated in the partially molten and weak middle crust at a depth where gravitational instabilities overcome the horizontal compressional forces (Fig. 16B). With ongoing D2 thinning, the S2 penetrative foliation may have formed a large-scale and flatlying mechanical anisotropy in the middle crust that controlled the emplacement of sheet-shaped granitoid plutons fed through melt ascension along proto-D3 strike-slip shear zones (Fig. 16C). At that stage, the upper-middle crust is preponderantly subjected to gravitational instabilities while the middle-lower crust is subjected to compressional tectonic forces. We consider that the TDZ first onset as a proto-D3 TDZ in the partially molten infrastructure and acted as a preferential magma pathway leading to the ascent of early magmatic pulses of the Tournefort diorite and Saint Arnac granite, emplaced between 308 and $304 \mathrm{Ma}$ at the bottom of the flat lying D2 domain (Fig. 16C). In the upper crust, the syn-orogenic extension is achieved by kilometer scale low-angle brittle normal faults.

In response to ongoing crustal thinning and granitoid emplacements, the anatectic front advanced upward, driving broadening of the flat-lying S2 domain while more evolved magmas intruded into the upper low-grade crust. Thinning is shifted to the upper crust with the likely growth of pull-apart basins.

After thermal and magmatic peak activity and during subsequent cooling, D2 thinning localized along more discrete shear zones forming a lens-shaped anastomosed network (Fig. 16D). Some late pegmatites intruding the low-grade schists are strongly mylonitized whereas others escaped the heterogeneous late-D2 deformation. D2 is now restricted to the upper crust where dextral pull-apart basins developed in which lateCarboniferous to early Permian sediments deposited. In the same time, strike-slip shear zones under transpression are growing further in the lower-middle crust dominated by ongoing convergence.

The final stage corresponds to the D3 subhorizontal shortening that overcomes extensional shearing. D3 developed open to tight folds and S3 foliation. In the infrastructure, TDZ widened and migrated upward due to ongoing strike-slip shearing under transpression (Fig. 16E). A pinched synform of the suprastructural schist and micaschists develops along the TDZ.

The progressive switch from thinning to transpression is attributed to the lessening of gravitational forces at an advanced stage of extensional collapse that became overcome by ongoing compressional tectonic forces. In that case, a change in the far field stress is not necessary since the driving mechanism is the fall of gravity forces. However, extension in the core of the orogenic plateau is a potential driving mechanism responsible for shortening of the foreland domain (Teyssier et al., 2008). N-S extension and lateral flow of the partially molten crust recorded in the collapsing French Massif Central may have provoked compression in the Agly massif. Following Cochelin et al. (2017), it is likely that a rise of compressional forces may has occurred in response to the closure of the Ibero-Armorcian Arc and has been responsible for dextral transpression during early Permian.

\section{Conclusion}

Structural analysis of the Paleozoic Variscan basement of the Agy massif shows that the apparent dome shape of the massif is the result of the superimposition of three major ductile deformations D1, D2, and D3. D1 deformation is preserved as relictual foliation in low strain zones and we speculate that it could be related to middle Carboniferous thickening and building of the orogenic plateau. D2 deformation is a heterogeneous non-coaxial deformation, affecting the whole massif, that produced a shallowly dipping $\mathrm{S} 2$ foliation, and an anastomosed network of $\mathrm{C} 2$ shear zones that accommodated vertical thinning and N20 directed extension. D2 is coeval with LP-HT metamorphism and plutonism at ca $315-295 \mathrm{Ma}$. D2 corresponds to the 


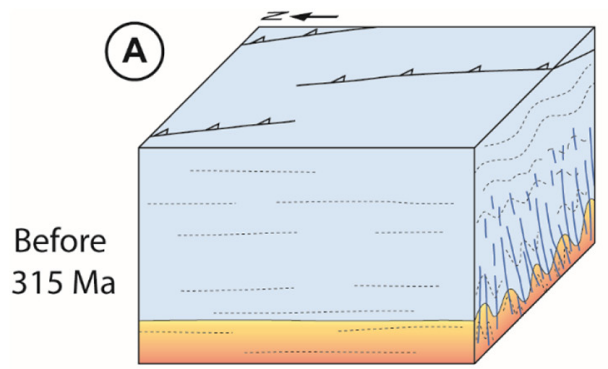

Crustal thickening

Thermal relaxation and

onset of the partial melting

Unknown compressional

stress direction

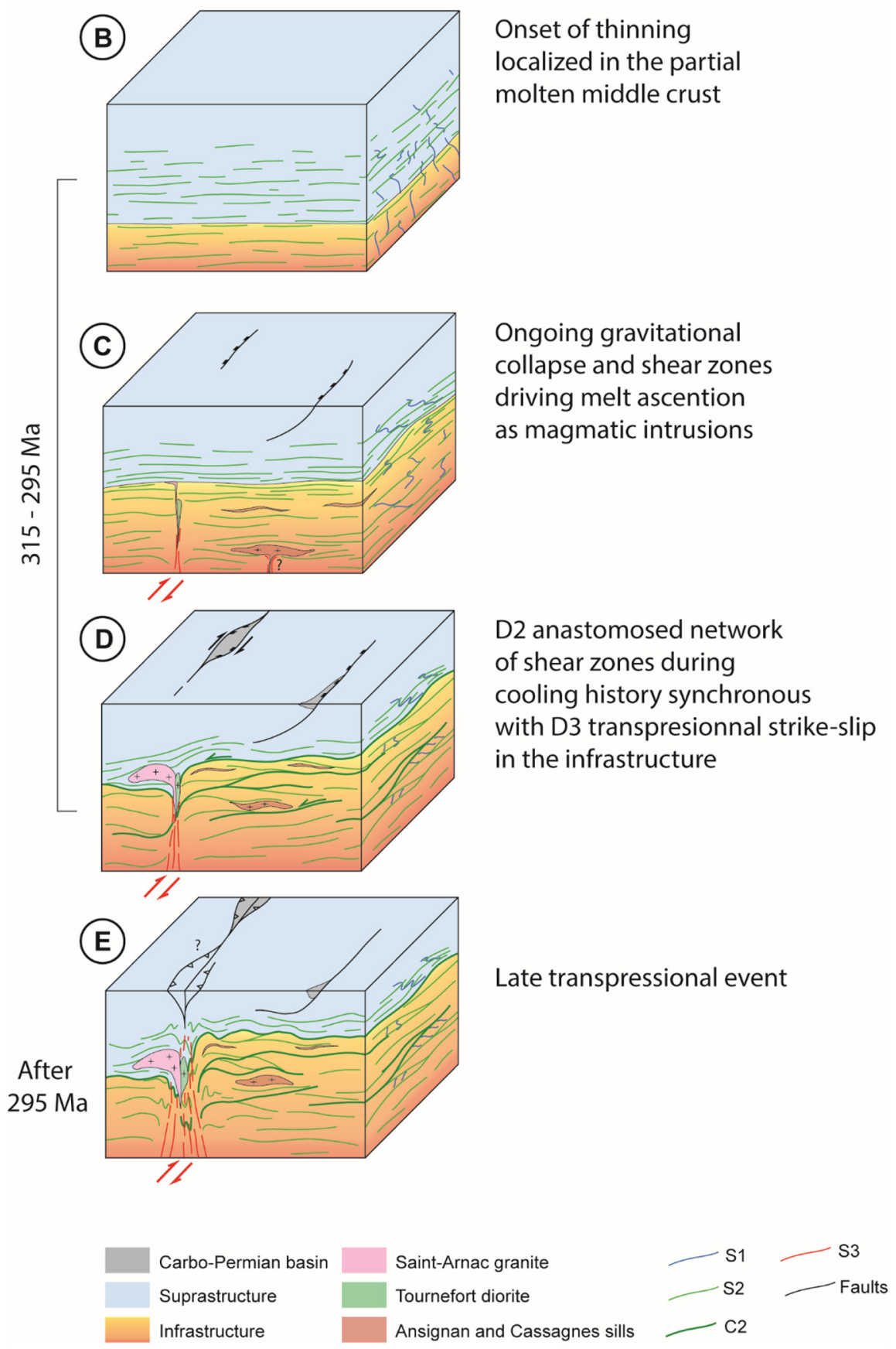

Fig. 16. Tectonic model showing the deformation history of the late-Variscan orogenic crust in the Agly massif. 
extensional collapse of the partially molten orogenic crust in a global dextral strike-slip at the scale of the whole Variscan belt. D3 deformation is a record of E-W striking dextral shearing that facilitated and localized the ascent and emplacement of the Tournefort diorite and the Saint-Arnac granite. D3 outlasted D2 and turned compressional in response to the closure of the Ibero-Armorican Arc.

The ductile deformation and HT metamorphism observed in the Paleozoic basement of the Agly massif are related to the late Carboniferous to early Permian tectonic. Cretaceous extension did not impact the Variscan tectono-thermal record but was only expressed as the hydrothermal alteration localized along N100 faults. Tertiary Pyrenean collision is responsible for the final thrusting of the Agly massif upon the Saint-Paul-de-Fenouillet basin as well as the local pinching and incorporation of weakly metamorphosed Mesozoic limestones into the gneissic basement.

Acknowledgement. This work was supported by the BRGM through the Référentiel Géologique de la France program (RGF). Philippe Olivier and Sebastien Ternois are gratefully acknowledged for stimulating discussions. Didier Convert provided generous support with thin section preparation. The newly acquired and compiled structural data will be available on the RGF website (http://rgf.brgm.fr).

\section{References}

Aguilar C, Liesa M, Castiñeiras P, Navidad M. 2013. Late Variscan metamorphic and magmatic evolution in the eastern Pyrenees revealed by $\mathrm{U}-\mathrm{Pb}$ age zircon dating. J Geol Soc London 171: 181-192.

Aguilar C, Liesa M, Štípská P, Schulmann K, Muñoz JA, Casas JM. 2015. P-T-t-d evolution of orogenic middle crust of the Roc de Frausa Massif (Eastern Pyrenees): A result of horizontal crustal flow and Carboniferous doming? J Metamorph Geol 33: 273-294.

Althoff F, Barbey P, Pons J. 1994. La charnockite d'Ansignan et le granite de Saint-Arnac, témoins d'une extension crustale d'âge hercynien dans le massif de l'Agly (Pyrénées Orientales, France). C R Acad Sci Paris 319: 239-246.

Andrieux P. 1982a. Conditions de cristallisation et évolution paragénétique d'une charnockite hercynienne : le complexe granulitique d'Ansignan (massif de l'Agly, Pyrénées-Orientales). $B$ Minéral 105: 253-266.

Andrieux P. 1982b. La charnockite d'Ansignan (Massif d'Agly, Pyrénées Orientales). Mise en place et évolution paragénétique. Introduction à l'étude des équilibres grenat-orthopyroxène. 3rd Cycle Thesis, Clermont-Ferrand (France), Univ. Blaise Pascal.

Antolín-Tomás B, Román-Berdiel T, Casas-Sainz A, Gil-Peña I, Oliva B, Soto R. 2009. Structural and magnetic fabric study of the Marimanha granite (Axial Zone of the Pyrenees). Int J Earth Sci 98: 427-441.

Auréjac JB, Gleizes G, Diot H, Bouchez JL. 2004. Le complexe granitique de Quérigut (Pyrénées, France) ré-examiné par la technique de l'ASM : un pluton syntectonique de la transpression dextre hercynienne. Bull Soc geol Fr 175: 157-174.

Ayora C, Liesa M, Delgado J. 1993. Low-thermal-gradient Hercynian metamorphism in the eastern Pyrenees. JMetamorph Geol 11:49-58.

Azambre B, Guitard G. 2001. Disthène et staurotide reliques dans les métapélites du Canigou (Pyrénées orientales). Relations avec les épisodes hercyniens de basses et moyennes pressions. C R Acad Sci Paris 333: 601-609.
Azambre B, Ravier J. 1978. Les écailles de gneiss du faciès granulite $\mathrm{du}$ Port de Saleix et de la région de Lherz (Ariège), nouveaux témoins du socle profond des Pyrénées. Bull Soc geol Fr 7: 221-228.

Barbey P, Villaros A, Marignac C, Montel JM. 2015. Multiphase melting, magma emplacement and P-T-time path in late-collisional context: The Velay example (Massif Central, France). Bull Soc geol Fr 186: 93-116.

Berger GM, Fonteilles M, Leblanc D, Clauzon G, Marchal JP, Vautrelle C. 1993. Notice de la carte géologique de la France, feuille Rivesaltes (1090), scale 1:50 000. Orléans : BRGM.

Besson M. 1974. Présence de disthène dans les gneiss du massif de l'Aston. Bull Soc Fr Minéral Cristallogr 97: 487-490.

Bouchez JL, Gleizes G. 1995. Two stage deformation of the MontLouis-Andorra granite pluton (Variscan Pyrenees) inferred from magnetic susceptibility anisotropy. J Geol Soc 152: 669-679.

Bouchez JL, Delas D, Gleizes G, Nedelec A, Cuney M. 1992. Submagmatic microfractures in granites. Geology 20:35-38.

Bouchez JL, Nguema TMM, Esteban L, Siqueira R, Scrivener R. 2006. The tourmaline-bearing granite pluton of Bodmin (Cornwall, UK): Magnetic fabric study and regional inference. J Geol Soc 163: 607-616.

Bouhallier H, Choukroune P, Ballevre M. 1991. Evolution structurale de la croûte profonde hercynienne: exemple du massif de l'agly (pyrenees-orientales, france). C R Acad Sci Paris 312: 647-654.

Boulvais P. 2016. Fluid generation in the Boucheville Basin as a consequence of the North Pyrenean Metamorphism. C R Geosci 348: 301-311.

Burg JP, Vanderhaeghe O. 1993. Structures and way-up criteria in migmatites, with application to the Velay dome (French Massif Central). J Struct Geol 15: 1293-1301.

Burg JP, Van Den Driessche J, Brun JP. 1994. Syn- to post-thickening extension in the Variscan Belt of Western Europe: Modes and structural consequences. Géologie de la France 3: 33-51.

Carreras J, Capella I. 1994. Tectonic levels in the Palaeozoic basement of the Pyrenees: A review and a new interpretation. $J$ Struct Geol 16: 1509-1524.

Carreras J, Druguet E. 2014. Framing the tectonic regime of the NE Iberian Variscan segment. Geol Soc Spec Publ London 405. https:// doi.org/10.1144/SP405.7.

Casas JM, Palacios T. 2012. First biostratigraphical constraints on the pre-Upper Ordovician sequences of the Pyrenees based on organicwalled microfossils. $C R$ Geosci 344: 50-56.

Casas JM, Fernández O, Domingo F. 2007. Carboniferous normal faults in the Eastern Pyrenees: Evidences and age constrains of synorogenic Variscan extension. Geodin Acta 20: 385-392.

Chelalou R. 2015. Formation et évolution du bassin de Boucheville, implication sur l'évolution tectonique, métamorphique et sédimentaires des bassins sédimentaires mésozoïques du Nord-Est des Pyrénées. PhD thesis, Rennes (France), Univ. Rennes 1.

Chelalou R, Nalpas T, Bousquet R, Prevost M, Lahfid A, Poujol M, et al. 2016. New Sedimentological, Structural and PaleoThermicity Data in the Boucheville Basin (Eastern North Pyrenean Zone, France). C R Geosci 348: 312-321.

Clerc C. 2012. Évolution du domaine nord-pyrénéen au Crétacé. Amincissement crustal extrême et thermicité élevée : un analogue pour les marges passives. PhD thesis, Paris (France), Univ. Pierre et Marie Curie-Paris VI.

Clerc C, Lagabrielle Y. 2014. Thermal control on the modes of crustal thinning leading to mantle exhumation: Insights from the Cretaceous Pyrenean hot paleomargins. Tectonics 33: 1340-1359.

Clerc C, Lagabrielle Y, Neumaier M, Reynaud JY, St Blanquat M. 2012. Exhumation of subcontinental mantle rocks: Evidence from 
ultramafic-bearing clastic deposits nearby the Lherz peridotite body, French Pyrenees. Bull Soc geol Fr 183: 443-459.

Clerc C, Boulvais P, Lagabrielle Y, Blanquat M. 2013. Ophicalcites from the northern Pyrenean belt: A field, petrographic and stable isotope study. Int J Earth Sci 103: 141-163.

Clerc C, Lahfid A, Monié P, Lagabrielle Y, Chopin C. 2015. Hightemperature metamorphism during extreme thinning of the continental crust: A reappraisal of the North Pyrenean passive paleomargin. Solid Earth 6: 643-668.

Clerc C, Lagabrielle Y, Labaume P, Ringenbach JC, Vauchez A, Nalpas T, et al. 2016. Basement-Cover decoupling and progressive exhumation of metamorphic sediments at hot rifted margin. Insights from the Northeastern Pyrenean analog. Tectonophysics 686: 82-97.

Cochelin B. 2016. Champ de déformation du socle paléozoïque des Pyrénées. PhD thesis, Toulouse (France), Univ. Paul Sabatier.

Cochelin B, Chardon D, Denèle Y, Gumiaux C, Le Bayon B. 2017. Vertical strain partitioning in hot Variscan crust: Syn-convergence escape of the Pyrenees in the Iberian-Armorican syntax. Bull Soc geol Fr 188. https://doi.org/10.1051/bsgf/2017206.

Corre B, Boulvais P, Boiron MC, Lagabrielle Y, Marasi L, Clerc C. 2018. Fluid circulations in response to mantle exhumation at the passive margin setting in the north Pyrenean zone, France. Mineral Petrol 112: 1-24.

Couzinié S, Laurent O, Moyen JF, Zeh A, Bouilhol P, Villaros A. 2016. Post-collisional magmatism: Crustal growth not identified by zircon Hf-O isotopes. Earth Planet Sci Lett 456: 182-195.

de Hoÿm de Marien L, Le Bayon B, Pitra P, Van Den Driessche J, Poujol M, Cagnard F. 2018. Two-stage Variscan metamorphism in the Canigou massif: Evidence for crustal thickening in the Pyrenees. J Metamorph Geol 37: 863-888.

de Saint Blanquat M. 1989. La faille normale ductile du massif du Saint Barthélémy. Age et signification de l'extension crustale dans le zone Nord-pyrénéenne. PhD thesis, Montpellier (France), Univ. Montpellier 2.

de Saint Blanquat M. 1993. La faille normale ductile du massif de Saint-Barthélémy. Évolution hercynienne des massifs nordpyrénéens catazonaux considérée du point de vue de leur histoire thermique. Geodin Acta 6: 59-77.

de Saint Blanquat M., Lardeaux JM, Brunel M. 1990. Petrological arguments for high-temperature extensional deformation in the Pyrenean Variscan crust (Saint Barthélémy Massif, Ariège, France). Tectonophysics 177: 245-262.

Debroas EJ, Canérot J, Bilotte M. 2010. Les Brèches d'Urdach, témoins de l'exhumation du manteau pyrénéen dans un escarpement de faille vraconnien-cénomanien inférieur (zone nordpyrénéenne, Pyrénées-Atlantiques, France). Geol Fr 2: 53-64.

Delaperrière E, de Saint-Blanquat M, Brunel M, Lancelot JR. 1994. Geochronologie U-Pb sur zircons et monazites dans le massif du Saint Barthelemy (Pyrenees, France); discussion des âges des évènements varisques et pré-varisques. Bull Soc geol Fr 165: 101-112.

Delay F. 1989. Le massif nord-pyrénéen de l'Agly (Pyrénées orientales): Évolution tectono-métamorphique et exemple d'un amincissement crustal polyphasé. $\mathrm{PhD}$ thesis, Lille (France), Univ. Lille 1.

Denèle Y, Olivier P, Gleizes G, Barbey P. 2009. Decoupling between the Middle and Upper Crust during Transpression-Related Lateral Flow: Variscan Evolution of the Aston Gneiss Dome (Pyrenees, France). Tectonophysics 477: 244-261.

Denèle Y, Laumonier L, Paquette JL, Olivier P, Gleizes G, Barbey P. 2014. Timing of granite emplacement, crustal flow and gneiss dome formation in the Variscan segment of the Pyrenees. Geol Soc London Spec Publ 405: 265-287.
Dewey JF. 1988. Extensional collapse of orogens. Tectonics 7: 1123-1139.

Dörr W, Zulauf G. 2010. Elevator tectonics and orogenic collapse of a Tibetan-style plateau in the European Variscides: The role of the Bohemian shear zone. Int J Earth Sci 99: 299-325.

Druguet E. 1997. The structure of the NE Cap de Creus NE peninsula. Relationships with metamorphism and magmatism. PhD thesis, Barcelona (Spain), Univ. Autónoma de Barcelona.

Druguet E. 2001. Development of High Thermal Gradients by Coeval Transpression and Magmatism during the Variscan Orogeny: Insights from the Cap de Creus (Eastern Pyrenees). Tectonophysics 332: 275-293.

Druguet E, Castro A, Chichorro M, Pereira MF, Fernández C. 2014. Zircon geochronology of intrusive rocks from Cap de Creus, Eastern Pyrenees. Geol Mag 151: 1095-1114.

Ducoux M. 2017. Structure, thermicité et évolution géodynamique de la Zone Interne Métamorphique des Pyrénées. PhD thesis, Orléans (France), Univ. d'Orléans.

Edel JB, Schulmann K, Lexa O, Lardeaux JM. 2018. Late Palaeozoic palaeomagnetic and tectonic constraints for amalgamation of Pangea supercontinent in the European Variscan belt. Earth Sci Rev 177: 589-612.

Fallourd S, Poujol M, Boulvais P, Paquette JL, de Saint Blanquat M, Rémy P. 2014. In Situ LA-ICP-MS U-Pb titanite dating of $\mathrm{Na}-\mathrm{Ca}$ metasomatism in orogenic belts: The North Pyrenean example. Int $J$ Earth Sci 103: 667-682.

Faure M. 1995. Late orogenic carboniferous extensions in the Variscan French Massif Central. Tectonics 14: 132-153.

Faure M, Lardeaux JM, Ledru P. 2009. A review of the pre-Permian geology of the Variscan French Massif Central. C R Geosci 341: 202-213.

Fonteilles M. 1970. Géologie des terrains métamorphiques et granitiques du massif hercynien de l'Agly (Pyrénées orientales). Bull BRGM 3: 1-54.

Fonteilles M. 1976. Essai d'interprétation des compositions chimiques des roches d'origine métamorphique et magmatique du massif hercynien de l'Agly (Pyrénées Orientales). State thesis, Paris (France), Univ. Paris VI.

Fonteilles M, Guitard G. 1971. Disthène relique et disthène hystérogène dans les terrains métamorphiques hercyniens des Pyrénées orientales franco-espagnoles. C R Acad Sci Paris 272: 361-363.

Fonteilles M, Guitard G, Raguin E. 1964. Sur la présence de gneiss à disthène et cordiérite dans le massif du Saint-Barthélémy (Pyrénées de 1'Ariège). C R Acad Sci Paris 258: 3524-3525.

Fonteilles M, Leblanc D, Clauzon G, Vaudin JL, Berger GM. 1993. Carte géologique de la France, feuille Rivesaltes (1090), scale 1:50 000. Orléans : BRGM.

Fossen H, Tikoff B. 1993. The deformation matrix for simultaneous simple shearing, pure shearing and volume change, and its application to transpression-transtension tectonics. J Struct Geol 15: 413-422.

Franke W, Doublier MP, Klama K, Potel S, Wemmer K. 2011. Hot metamorphic core complex in a cold foreland. Int J Earth Sci 100: 753-785.

Fréville K, Cenki-Tok B, Trap P, Rabin M, Leyreloup A, Régnier JL, et al. 2016. Thermal interaction of middle and upper crust during gneiss dome formation: Example from the Montagne Noire (French Massif Central). J Metamorph Geol 34: 447-462.

Gébelin A, Brunel M, Monié P, Faure M, Arnaud N. 2007. Transpressional tectonics and Carboniferous magmatism in the Limousin, Massif Central, France: Structural and ${ }^{40} \mathrm{Ar} /{ }^{39} \mathrm{Ar}$ investigations. Tectonics 26. https://doi.org/10.1029/ 2005TC001822. 
Gébelin A, Roger F, Brunel M. 2009. Syntectonic crustal melting and high-grade metamorphism in a transpressional regime, Variscan Massif Central, France. Tectonophysics 477: 229-243.

Gibson R. 1991. Hercynian low-pressure-high-temperature regional metamorphism and subhorizontal foliation development in the Canigou massif, Pyrenees, France-Evidence for crustal extension. Geology 19: 380-383.

Gleizes G, Bouchez JL, Lespinasse P, Roux L. 1992. Structure du granite de Lacourt (Arize occidentale) : une signature syntectonique de phase 2 dans l'Hercynien des Pyrénées. Bull Soc Hist Nat Toulouse 128: 53-57.

Gleizes G, Leblanc D, Bouchez JL. 1997. Variscan Granites of the Pyrenees Revisited: Their Role as Syntectonic Markers of the Orogen. Terra Nova 9: 38-41.

Gleizes G, Leblanc D, Bouchez JL. 1998a. The main phase of the Hercynian orogeny in the Pyrenees is a dextral transpression. Geol Soc London Spec Publ 135: 267-273.

Gleizes G, Leblanc D, Santana V, Olivier O, Bouchez JL. 1998b. Sigmoidal structures featuring dextral shear during emplacement of the Hercynian granite complex of Cauterets-Panticosa (Pyrenees). J Struct Geol 20: 1229-1245.

Gleizes G, Leblanc D, Olivier P, Bouchez JL. 2001. Strain partitioning in a pluton during emplacement in transpressional regime: The Example of the Néouvielle Granite (Pyrenees). Int $J$ Earth Sci 90: 325-340.

Gleizes G, Crevon G, Asrat A, Barbey P. 2006. Structure, age and mode of emplacement of the Hercynian Bordères-Louron pluton (Central Pyrenees, France). Int J Earth Sci 95: 1039-1052.

Golberg JM, Leyreloup AF. 1990. High temperature-low pressure Cretaceous metamorphism related to crustal thinning (Eastern North Pyrenean Zone, France). Contrib Mineral Petrol 104: 194-207.

Greene D, Schweickert R. 1995. The Gem Lake shear zone: Cretaceous dextral transpression in the Northern Ritter Range pendant, eastern Sierra Nevada, California. Tectonics 14: 945-961.

Guitard G, Vielzeuf D, Martinez F. 1996. Le métamorphisme hercynien. In: Chiron JC, Barnolas A, eds. Synthèse géologique et géophysique des Pyrénées. Orléans (France): Bureau de Recherches Géologiques et Minières, vol. 1, pp. 501-584.

Hart NR, Stockl, DF, Hayman NW. 2016. Provenance evolution during progressive rifting and hyperextension using bedrock and detrital zircon U-Pb geochronology, Mauléon Basin, western Pyrenees. Geosphere 12: 1166-1186.

Hibbard MJ. 1987. Deformation of incompletely crystallized magma systems: Granitic gneisses and their implications. J Geol 95: 543-561.

Hilario Orús A. 2004. Relación entre magmatismo y deformación en la transversal de Benasque a Luchon (Zona Axial del Pirineo). Tesis Doctoral, Leioa (Spain), Univ. del País Vasco.

Izquierdo-Llavall E, Román-Berdiel T, Casas AM, Oliva-Urcia B, Gil-Peña I, Soto R, et al. 2012. Magnetic and structural study of the Eaux-Chaudes intrusion: Understanding the Variscan deformation in the Western Axial Zone (Pyrenees). Int J Earth Sci 101: $1817-1834$.

Jammes S, Manatschal G, Lavier LL, Masini E. 2009. Tectonosedimentary evolution related to extreme crustal thinning ahead of a propagating ocean: Example of the western Pyrenees. Tectonics 28. https://doi.org/10.1029/2008TC002406.

Lagabrielle Y, Bodinier JL. 2008. Submarine reworking of exhumed subcontinental mantle rocks: Field evidence from the Lherz peridotites, French Pyrenees. Terra Nova 20: 11-21.

Lagabrielle Y, Labaume P, St Blanquat M. 2010. Mantle exhumation, crustal denudation, and gravity tectonics during Cretaceous rifting in the Pyrenean realm (SW Europe): Insights from the geological setting of the lherzolite bodies. Tectonics 29. https://doi.org/ 10.1029/2009TC002588.

Lagabrielle Y, Clerc C, Vauchez A, Lahfid A, Labaume P, Azambre $\mathrm{B}$, et al. 2016. Very High Geothermal Gradient during Mantle Exhumation Recorded in Mylonitic Marbles and Carbonate Breccias from a Mesozoic Pyrenean Palaeomargin (Lherz Area, North Pyrenean Zone, France). C R Geosci 348: 290-300.

Laumonier B. 1998. Les Pyrénées centrales et orientales au début du Paléozoique (Cambrien s.l.) : évolution paléogéographique et géodynamique. Geodin Acta 11: 1-11.

Laumonier B, Marignac C, Kister P. 2010. Polymétamorphisme et évolution crustale dans les Pyrenees Orientales pendant l'orogénèse Varisque au Carbonifère supérieur. Bull Soc geol Fr 181: 411-428.

Leblanc D, Gleizes G, Lespinasse P, Olivier P, Bouchez JL. 1993. The Maladeta granite polydiapir, Spanish Pyrenees: A detailed magnetostructural study. J Struct Geol 16: 223-235.

Leblanc D, Gleizes G, Roux L, Bouchez JL. 1996. Variscan dextral transpression in the French Pyrenees: New data from the Pit des Trois-Seigneurs granodiorite and its country rocks. Tectonophysics 261: 331-345.

Ledru P, Courrioux G, Dallain C, Lardeaux JM, Montel JM, Vanderhaeghe O, et al. 2001. The Velay dome (French Massif Central): Melt generation and granite emplacement during orogenic evolution. Tectonophysics 342: 207-237.

Lemirre B. 2016. Origine et développement de la thermicité dans les Pyrénées varisques. $\mathrm{PhD}$ thesis, Toulouse (France), Univ. Toulouse.

Maierová P, Schulmann K, Lexa O, Guillot S, Štípská P, Janoušek V, et al. 2016. European Variscan orogenic evolution as an analogueof Tibetan-Himalayan orogen: Insights frompetrology and numerical modeling. Tectonics 35: 1760-1780.

Malavieille J, Guihot P, Costa S, Lardeaux JM, Gardien V. 1990. Collapse of a thickened Variscan crust in the French Massif Central: Mont-Pilat extensional shear zone and Saint-Etienne Upper Carboniferous basin. Tectonophysics 177: 139-149.

Marmo V. 1971. Granite petrology and the granite problem: Amsterdam: Elsevier, 244 p.

Masini E, Manatschal G, Tugend J, Mohn G. 2014. The tectonosedimentary evolution of a hyper-extended rift basin: The example of the Arzacq-Mauléon rift system (Western Pyrenees, SW France). Int J Earth Sci 103: 1565-1596.

Matte P. 2002. Les plis hercyniens kilométriques couchés vers l'ouest-sud-ouest dans la région du pic du Midi d'Ossau-col du Somport (zone axiale des Pyrénées occidentales). C R Geosci 334: 773-779.

Mezger J, Gerdes A. 2016. Early Variscan (Visean) granites in the core of central Pyrenean gneiss domes: Implications from laser ablation U-Pb and Th-Pb studies. Gondwana Res 29: 181-198.

Mezger J, Passchier C. 2003. Polymetamorphism and ductile deformation of staurolite-cordierite schist of the Boss'ost dome: Indication for Variscan extension in the Axial Zone of the central Pyrenees. Geol Mag 140: 595-612.

Odlum ML, Stockli DF. 2019. Thermotectonic evolution of the North Pyrenean Agly Massif during Early Cretaceous hyperextension using multi-mineral U-Pb thermochronometry. Tectonics 38. https://doi.org/10.1029/2018TC005298.

Olivet JL. 1996. La cinématique de la plaque Ibérique. Bull Cent Rech Explor Prod Elf Aquitaine 20: 131-195.

Olivier P, Améglio L, Richen H, Vadeboin F. 1999. Emplacement of the Aya Variscan granitic pluton (Basque Pyrenees) in a dextral 
transcurrent regime inferred from a combined magneto-structural and gravimetric study. J Geol Soc London 156: 991-1002.

Olivier P, Gleizes G, Paquette JL. 2004. Gneiss domes and granite emplacement in an obliquely convergent regime: New interpretation of the Variscan agly massif (eastern pyrenees, france). Geol Soc Am sp pap 380: 229-240.

Olivier P, Gleizes G, Paquette JL, Muñoz Sáez C. 2008. Structure and $\mathrm{U}-\mathrm{Pb}$ dating of the Saint-Arnac pluton and the Ansignan Charnockite (Agly Massif): A cross-section from the upper to the middle crust of the Variscan Eastern Pyrenees. J Geol Soc 165: 141-52.

Olivier P, Druguet E, Castaño L M, Gleizes G. 2016. Granitoid emplacement by multiple sheeting during Variscan dextral transpression: The Saint-Laurent- La Jonquera pluton (Eastern Pyrenees). J Struct Geol 82: 80-92.

Paquet J, Delay F. 1989. Analyse en microscopie électronique des textures et des phases des mylonites nord-pyrénéennes des massifs de St-Barthélémy et de l'Agly et discussion des âges. Bull Soc geol Fr 8: 1111-1122.

Paquet J, Mansy JL. 1991. The structure of the Eastern Pyrenees (transect of the Agly massif): An example of crustal thinning. $C R$ Acad Sci Paris 312: 913-919.

Paquet J, Mansy JL. 1992. Evolution alpine du massif nord-pyrénéen de l'Agly (Pyrénées-Orientales). C R Acad Sci Paris 315: 487-494.

Pascal ML, Fonteilles M, Guitard G. 1976. Contribution à l'étude géométrique des plissements superposés hercyniens des Pyrénées orientales : Paléozoïque épizonal du massif de l'Agly. Bull Soc geol Fr 18:1471-1487.

Pawley MJ, Collins WJ. 2002. The development of contrasting structures during the cooling and crystallisation of a syn-kinematic pluton. J Struct Geol 24: 469-483.

Pitra P, Poujol M, Van Den Driessche J, Poilvet JC, Paquette JL. 2012. Early Permian extensional shearing of an Ordovician granite: The Saint-Eutrope "C/S-like" orthogneiss (Montagne Noire, French Massif Central). C R Geosci 344: 377-384.

Postaire B. 1982. Systématique $\mathrm{Pb}$ commun et U-Pb sur zircons : applications aux roches de haut grade métamorphique impliquées dans la chaîne hercynienne (Europe de l'ouest) et aux granulites de Laponie (Finlande). Mémoires de la société géologique et minéralogique de Bretagne 15: 29-72.

Poujol M, Boulvais P, Kosler J. 2010. Regional-Scale Cretaceous Albitization in the Pyrenees: Evidence from in situ U-Th-Pb Dating of Monazite, Titanite and Zircon. J Geol Soc 167: 751-767.

Poujol M, Pitra P, Van Den Driessche J, Tartèse R, Ruffet G, Paquette JL, et al. 2017. Two-stage partial melting during the Variscan extensional tectonics (Montagne Noire, France). Int J Earth Sci 106: 477-500.

Rabin M, Trap P, Carry N, Fréville K, Cenki-Tok B, Lobjoie C, et al. 2015. Strain partitioning along the anatectic front in the Variscan Montagne Noire massif (Southern French Massif Central). Tectonics 34: 1709-1735.

Respaut JP, Lancelot JR. 1983. Datation de la mise en place synmétamorphe de la charnockite d'Ansignan (massif de l'Agly) par la méthode U/Pb sur zircons et monazites. Neues Jahrb Mineral Abh 147: 21-34.

Rey, P.F., Teyssier, C., Whitney, D.L., 2010. The limit of channel flow in orogenic plateaux. Lithosphere 2: 328-332.

Roger F, Teyssier C, Respaut JP, Rey PF, Jolivet M, Whitney DL, et al. 2015. Timing of formation and exhumation of the Montagne Noire double dome, French Massif Central. Tectonophysics 640 641: 53-69.

Román-Berdiel T, Casas AM, Oliva-Urcia B, Pueyo EL, Rillo C. 2004. The main Variscan deformation event in the Pyrenees: New data from the structural study of the Bielsa granite. J Struct Geol 26: 659-677.
Román-Berdiel T, Casas AM, Oliva-Urcia B, Pueyo EL, Liesa C, Soto R. 2006. The Variscan Millares granite (central Pyrenees): Pluton emplacement in a $\mathrm{T}$ fracture of a dextral shear zone. Geodin Acta 19: 197-211.

Roux L. 1977. L'évolution des roches du faciès granulite et le problème des ultramafites dans le massif de Castillon (Ariège). State thesis, Toulouse (France), Univ. Toulouse.

Sibuet JC, Srivastava SP, Spakman W. 2004. Pyrenean orogeny and plate kinematics. J Geophys Res Solid Earth 109. https://doi.org/ 10.1029/2003JB002514.

Siron G, Goncalves P, Marquer D. 2012. The origin of high geothermal gradient: Post-orogenic extension or large intrusion in the middle crust? A case study from the Agly Massif, French Pyrenees. Abstract, Variscan 2012 meeting, Sassari, Italy.

Siron G, Goncalves P, Marquer D, Pierre T, Paquette JL, Vanardois J. 2020. Contribution of magmatism, partial melting buffering and localized crustal thinning on the late-Variscan thermal structure of the Agly massif (French Pyrenees). J Metamorph Geol (in press). https://doi.org/10.1111/jmg.12549.

Soliva J. 1992. Les déformations ductiles dans la zone axiale des Pyrénées-Orientales : la convergence varisque, la mise en place des granites tardi-hercyniens, la convergence pyrénéenne. $\mathrm{PhD}$ thesis, Montpellier (France), Univ. Montpellier 2.

Teyssier C, Whitney DL, Rey P. 2008. Dynamic coupling and coeval contraction/extension in and around orogenic plateaux. American Geophysical Union, Fall Meeting 2008, Abstract \#T23C-2040.

Ternois S, Odlum M, Ford M, Pik R, Stockli D, Tibari B, et al. 2019. Thermochronological evidence of early orogenesis, eastern Pyrenees, France. Tectonics 38: 1308-1336.

Thiébaut J. 1964. Étude géologique du Massif de la forêt de Castillon. Bull Soc Hist Nat Toulouse 99: 363-389.

Tikoff B, Greene D. 1997. Stretching lineations in transpressional shear zones: An example from the Sierra Nevada Batholith, California. J Struct Geol 19: 29-39.

Tikoff B, Teyssier C. 1994. Strain modeling of displacement-field partitioning in transpressional orogens. J Struct Geol 16: 15751588.

Tournaire Guille B, Olivier P, Paquette JL, Bosse V, Guillaume D. 2018. Evolution of the middle crust of the Pyrenees during the Paleozoic: New data on the plutonic rocks from the North Pyrenean Agly Massif. Int J Earth Sci 108: 245-265.

Trap P, Roger F, Cenki-Tok B, Paquette JL. 2017. Timing and duration of partial melting and magmatism in the Variscan Montagne Noire gneiss dome (French Massif Central). Int J Earth Sci 106: 453-476.

Tugend J, Manatschal G, Kusznir NJ. 2015. Spatial and temporal evolution of hyperextended rift systems: Implication for the nature, kinematics, and timing of the Iberian-European plate boundary. Geology 43: 15-18.

Van Den Driessche J, Brun JP. 1992. Tectonic evolution of the Montagne Noire (French Massif Central): A model of extensional gneiss dome. Geodin Acta 5: 85-97.

Vanderhaeghe O, Burg JP, Teyssier C. 1999. Exhumation of migmatites in two collapsed orogens: Canadian Cordillera and French Variscides. Geological Society Special Publication 154: 181-204.

Vauchez A, Clerc C, Bestani L, Lagabrielle Y, Chauvet A, Lahfid A, et al. 2013. Preorogenic exhumation of the North Pyrenean Agly massif (Eastern Pyrenees, France). Tectonics 32: 95-106.

Vernon RH. 1991. Interpretation of microstructures of microgranitoid enclaves. In: Didier J, Barbarin B, eds. Enclaves and granite petrology. Developments in petrology 13. Amsterdam: Elsevier, pp. 277-291.

Vernon RH. 2000. Review of microstructural evidence of magmatic and solid-state flow. Electron Geosci 5: 1-23. 
Vielzeuf D. 1980. Orthopyroxene and cordierite secondary assemblages in the granulitic paragneisses from Lherz and Saleix (French Pyrenees). Bull Mineral 103: 66-78.

Vielzeuf D. 1984. Relations de phases dans le faciès granulite et implications géodynamiques. L'exemple des granulites des Pyrénées. State thesis, Clermont-Ferrand (France), Univ. Blaise Pascal.

Vilà M, Pin C, Liesa M, Enrique P. 2007. LPHT metamorphism in a late orogenic transpressional setting, Albera Massif, NE Iberia:
Implications for the geodynamic evolution of the Variscan Pyrenees. J metamorph Geol 25: 321-347.

Vissers R. 1992. Variscan extension in the Pyrenees. Tectonics 11: 1369-1384.

Whitney DL, Roger F, Teyssier C, Rey PF, Respaut JP. 2015. Syncollapse eclogite metamorphism and exhumation of deep crust in a migmatite dome: The $\mathrm{P}-\mathrm{T}-\mathrm{t}$ record of the youngest Variscan eclogite (Montagne Noire, French Massif Central). Earth Planet Sci Lett 430: 224-234.

Cite this article as: Vanardois J, Trap P, Goncalves P, Marquer D, Gremmel J, Siron G, Baudin T. 2020. Kinematics, deformation partitioning and late Variscan magmatism in the Agly massif, Eastern Pyrenees, France, BSGF - Earth Sciences Bulletin 191: 15. 